Mineralogy and Petrology (2001) 71: 95-126

\title{
Mineralogy and Petrology
}

(C) Springer-Verlag 2001

Printed in Austria

\section{Metamorphic evolution of the Sierras de San Luis, Argentina: granulite facies metamorphism related to mafic intrusions}

\author{
C. A. Hauzenberger ${ }^{1}$, A. Mogessie ${ }^{1}$, G. Hoinkes ${ }^{1}$, A. Felfernig ${ }^{1}$, \\ E. A. Bjerg ${ }^{2,3}$, J. Kostadinoff ${ }^{2,3}$, S. Delpino ${ }^{2}$, and L. Dimieri ${ }^{2,3}$ \\ ${ }^{1}$ Institute of Mineralogy and Petrology, Karl-Franzens University Graz, Graz, Austria \\ ${ }^{2}$ Department of Geology, Universidad Nacional del Sur, Bahia Blanca, Argentina \\ ${ }^{3}$ CONICET, Bahia Blanca, Argentina
}

With 8 Figures

Received January 10, 2000;

revised version accepted June 7, 2000

\begin{abstract}
Summary
The Sierras de San Luis, which are part of the Sierras Pampeanas, are located in Central Argentina. The crystalline basement of the Sierras de San Luis is built up of three main blocks (western block, central block, and eastern block), which are separated by mylonite zones. The western and the eastern block are dominated by migmatites, whereas the central block is mostly lower in metamorphic grade ranging from greenschist facies to amphibolite facies, and locally to granulite facies in the vicinity of numerous mafic bodies. Most parts of the central block is built up of amphibolite facies rocks. These were formed during a first metamorphic event (M1-A) which is characterized by a mineral assemblage of staurolite-garnet-biotite-muscoviteplagioclase -quartz-ilmenite \pm fibrolite \pm chlorite. The $P T$ conditions of M1-A are about $570^{\circ} \mathrm{C}$ to $600^{\circ} \mathrm{C}$ and 5 to $5.7 \mathrm{kbar}$. A mafic intrusion, now seen as numerous mafic lenses included in the basement rocks caused local granulite facies metamorphism. The observed mineral assemblage consists of garnet-cordierite-sillimanite-biotite-Kfeldspar-plagioclase-quartz-rutile-ilmenite \pm orthopyroxene (M2-G). The PT estimates for granulite facies conditions are $740{ }^{\circ} \mathrm{C}$ to $790^{\circ} \mathrm{C}$ and 5.7 to $6.4 \mathrm{kbar}$. During cooling a mylonite zone developed within the central block retrograding most of the granulite facies rocks to amphibolite facies conditions. The newly formed mineral assemblage consists of garnet-biotite-sillimanite-plagioclase-muscovite-quartzrutile $\pm \mathrm{K}$-feldspar (M3-A). The $P T$ estimates of the locally overprinting second amphibolite facies event (M3-A) are about $590^{\circ} \mathrm{C}$ to $650^{\circ} \mathrm{C}$ and 5.4 to $6.0 \mathrm{kbar}$. The deduced $P T$ path shows a near isobaric heating from M1-A to M2-G. The mylonite mineral assemblage M3-A equilibrated at pressures close to M2-G. The $P T$ path can be
\end{abstract}


explained best by heating of an amphibolite facies middle crust by a mafic intrusion. During near-isobaric cooling tectonic activity in discrete parts of the basement caused mylonitization at amphibolite facies conditions.

\section{Zusammenfassung}

Die metamorphe Entwicklung der Sierras de San Luis: Granulitfazielle Metamorphose gebunden an mafische Intrusionen

Die Sierras de San Luis sind Teil der in Zentralargentinien gelegenen Sierras Pampeanas. Das kristalline Basement wird aus drei großen Blöcken aufgebaut (westlicher, zentraler und östlicher Block), die durch Mylonitzonen getrennt sind. Der westliche und östliche Block bestehen hauptsächlich aus Migmatiten, der zentrale Block ist dagegen aus etwas niedriggradigeren Gesteinen aufgebaut (grünschiefer- bis amphibolitfaziell). In der Umgebung der zahlreichen mafischen Gesteinslinsen erreicht die Metamorphose im zentralen Block granulitfazielle Bedingungen. Die Hauptmasse des zentralen Blocks besteht jedoch aus amphibolitfaziellen Gesteinen. Diese wurden im Zuge einer ersten Phase (M1-A) gebildet und bestehen aus der Mineralgesellschaft Staurolit-Granat-Biotit-Muscovit-Plagioklas-Quarz-Ilmenit \pm Fibrolit \pm Chlorit. Die $P T$ Bedingungen von M1-A wurden mit ca. $570^{\circ} \mathrm{C}$ bis $600^{\circ} \mathrm{C}$ und 5 bis $5.7 \mathrm{kbar}$ bestimmt. Eine mafische Intrusion, die im Gelände in der Form von zahlreichen Linsen auftritt, verursachte lokal granulitfazielle Metamorphose. Die neugebildete Mineralparagenese besteht aus Granat-Cordierit-Sillimanit-Biotit-K-Feldspat-Plagioklas-Quarz-Rutil-Ilmenit \pm Orthopyroxen (M2-G). Die $P T$ Bestimmung an diesen granulitfaziellen Gesteinen ergab Werte von $740^{\circ} \mathrm{C}$ bis $790^{\circ} \mathrm{C}$ und 5.7 bis $6.4 \mathrm{kbar}$. Im Zuge der Abkühlung des Basements bildeten sich mächtige Mylonitzonen aus, die den Großteil der granulitfaziellen Gesteine in amphibolitfazielle Paragenesen umwandelte. Die neu gebildete Mineralgesellschaft besteht aus Granat-Biotit-SillimanitPlagioklas-Muskovit-Quarz-Rutil \pm K-Feldspat (M3-A). Diese an die Mylonitzonen gebundene Mineralparagenese wurde bei $590^{\circ} \mathrm{C}$ bis $650^{\circ} \mathrm{C}$ and 5.4 to $6.0 \mathrm{kbar}$ gebildet. Der abgeleitete $P T$ Pfad zeigt ein nahezu isobares Aufheizen am prograden Pfad (M1A-M2-G), sowie eine anschließende retrograde Überprägung (M3-A) bei ebenfalls nahezu gleichem Druck. Der PT Pfad läßt sich am besten mit dem Aufheizen eines mittleren Krustensegments aufgrund einer mafischen Intrusion erklären. Im Zuge der isobaren Abkühlung führten tektonische Aktivitäten in diskreten Zonen des Basements zur Ausbildung von Mylonitzonen, die die Gesteine amphibolitfaziell überprägten.

\section{Introduction}

The Sierras Pampeanas province of Argentina is a high grade metamorphic complex on the eastern side of the Andean mountains that extends several hundred kilometers from north to south (Fig. 1). During the Andean tectonic events this complex was disected into several large fault blocks, which were uplifted by reverse faulting and local folding during the late Cenozoic. The present morphology and tectonic setting is very similar to that of the Rocky Mountain foreland province of the North American Cordillera (Jordan et al., 1983; Jordan and Allmendinger, 1986). Several workers have investigated the large Preandean crystalline blocks during the last 80 years (Gerth, 1913; Bonorino, 1961; Gordillo and Lencinas, 1979; Rapela and Shaw, 1979; Rapela et al., 1986, 1998; Ramos et al., 1986; dalla Salda, 1987; Jordan et al., 1983; Jordan and Allmendinger, 1986; Coira et al., 1982; Sims 


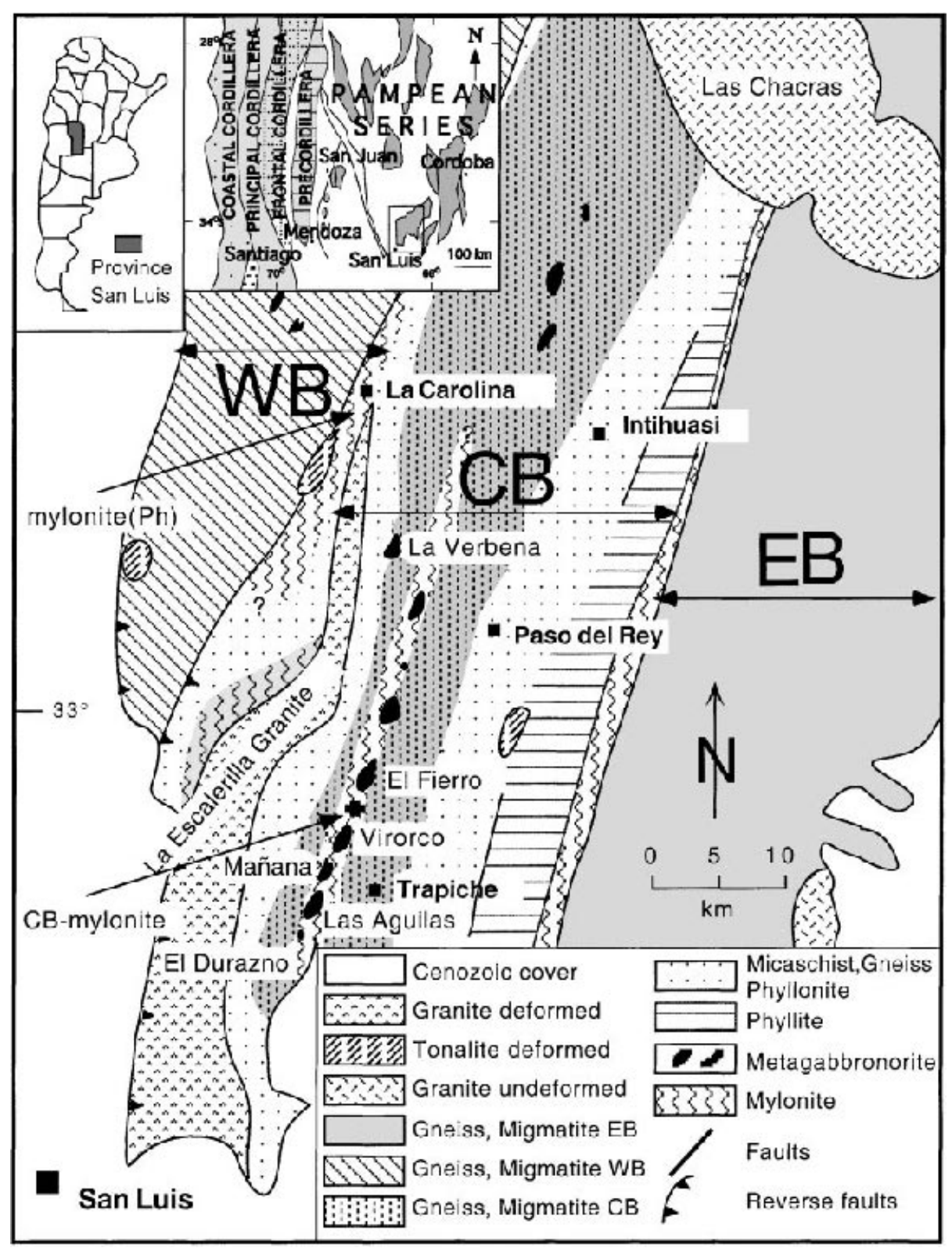

Fig. 1. Simplified geological map of the Sierras de San Luis. Modified after von Gosen (1998). $C B$ Central block, $E B$ Eastern block, WB Western block

et al., 1998; Gervilla et al., 1997; von Gosen, 1998; Llambias et al., 1998; Grissam et al., 1998). Most attention was paid to the huge granitic batholites (Rapela et al., 1986, 1995, 1982) or the abundant mafic-ultramafic bodies (Bonorino, 1961; Sabalua, 1986; Malvicini and Brogioni, 1992; Mogessie et al., 1994, 1995, 1996; Bjerg et al., 1997; Hauzenberger et al., 1996, 1997; Gervilla et al., 1997). The age of the crystalline basement ranges from Precambrian to Paleozoic (Sims et al., 1998; Rapela et al., 1998). In this paper, we present one of the first detailed descriptions of the metamorphic evolution during Preandean times of part of the Sierras 
Pampeanas, the Sierras de San Luis. We will present a quantitative $P T$ path of the area and use the metamorphic evolution of part of the range as a particularly good example to illustrate how advective heating mechanisms have caused regional granulite facies metamorphism.

\section{Geological setting}

The southwestern part of South America is a complex collage of cratonic blocks that were brought together along the southwestern margin of Gondwana/South America in the Phanerozoic. According to Pankhurst and Rapela (1998) four geological cycles have formed the Pacific margin of South America: (1) Pampean Orogeny (Neoproterozoic-Late Cambrian), (2) Famatinian Orogeny (Early Ordovician-Early Carboniferous), (3) Gondwanian Orogeny (Early Carboniferous-Early Cretaceous), and (4) Andean Orogeny (Early Cretaceous-Present).

The Sierras de San Luis are located between latitude $32^{\circ}-34^{\circ}$ South, and longitude $66^{\circ}-68^{\circ}$ West and are considered to be part of the Famatinian cycle (Rapela et al., 1998; Pankhurst et al., 1998; Llambias et al., 1998; Sims et al., 1998). The crystalline basement with a metamorphic grade ranging from greenschist to granulite facies is intruded by several plutonic bodies. Most of the deformed tonalites, granodiorites, monzogranites, and mafic intrusions show ages around 460 to 490 Ma (Llambias et al., 1998; Sims et al., 1998) indicating the Famatinian age of deformation and metamorphism of the Sierras de San Luis.

The southern part of the Sierras de San Luis consists of three main blocks: (1) the eastern block $(\mathrm{EB}=$ Conlara metamorphic complex $)$, comprised of mainly high grade gneisses and migmatites; (2) the central block $(\mathrm{CB}=$ Pringles metamorphic complex) which ranges in metamorphic grade from greenschist to granulite facies and comprises phyllites, micaschists, gneisses; migmatites, intercalated bodies of mafic and tonalitic-granodioritic intrusions and pegmatites; and (3) the western block (WB = Ngoli metamorphic complex) which consists mainly of migmatitic orthogneisses and high grade gneisses with lenses of amphibolites (Fig. 1). The three blocks are clearly separated by ductile shear zones recognised in the field as up to $5 \mathrm{~km}$ wide, lower to middle amphibolite facies grade mylonite zones (Fig. 1). A mylonite zone at upper amphibolite facies metamorphic grade is present within the CB. This mylonite zone is limited to the area where mafic intrusions are found and overprints the metamorphic assemblages as well as the structural elements of the CB (Fig. 1). The NNE - SSW striking basement is characterized by subvertical foliation planes with steeply plunging fold axes outside the $\mathrm{CB}$ mylonite zone. This deformation event is considered to be the earliest and is designated M1. The tectonic event that has led to the intrusion of the gabbronoritic bodies is described as M2 and the deformation causing the CB mylonite with its subvertical foliation planes, a steeply plunging lineation and subhorizontal fold axes is called M3. The $\mathrm{CB}$ mylonite zone locally retains relics of the earlier deformation, especially in zones where rocks have been protected from the third event. The grade of metamorphism varies from greenschist (M1-P) to amphibolite facies (M1-A) outside the CB-mylonite zone. Gabbronoritic bodies which are found within the CB-mylonite zone are associated with granulite facies rocks (M2-G). The CBmylonite zone overprinted the mafic lenses and associated granulite facies rocks 
(M2-G) and retrograded most of them to amphibolite facies (M3-A). Numerous granitic pegmatites occur as mainly concordant, up to several meter wide dykes in the basement and in the mafic bodies. Most of them are considered to be syn- or post tectonic with respect to the first deformation phase (M1).

The central block (CB) stands out because of the change in metamorphic grade from greenschist to granulite facies and the occurrence of metabasites within a sequence of quartzofeldspathic and pelitic metasediments. It forms the topic of this study.

\section{Analytical methods}

Approximately 400 thin sections from metapelites, metagranites, calcsilicates, and mafic-ultramafic rocks were investigated by a combination of transmitted and reflected light microscopy, and scanning electron microscope (SEM) analyses. The locations of samples used in this study are shown in Fig. 2. The mineral analyses were carried out at the Institut für Mineralogie und Petrologie, Universität Graz, with a JEOL 6310 SEM equipped with a LINK ISIS energy dispersive system and a MICROSPEC wavelength dispersive system. Standard analytical conditions for silicates were set to an accelerating voltage of $15 \mathrm{kV}$ and $5 \mathrm{nA}$ sample current. The matrix corrections of silicates were made using the ZAF procedure. The following mineral standards were used: Si, K (EDS): Adularia; Al (EDS): Adularia; Al (EDS): Andalusite; Fe (EDS), Mg (WDS): Garnet or Olivine; Ca, Ti (EDS): Titanite; Mn (EDS): Tephroite; Zn (EDS): Gahnite; Cr (EDS): synthetic Mg-Chromite; Cl (EDS): Atacamite; F (WDS): F-Apatite, Na (WDS): Jadeite. The practical detection limits in these routine analyses vary from 0.05 to $0.1 \mathrm{wt} \%$ for the MICROSPEC wavelength dispersive system, and 0.1 to $0.5 \mathrm{wt} \%$ for the LINK ISIS energy dispersive system. Geothermobarometric calculations were made with the Mathematica software package PET-Tools (Dachs, 1998).

\section{Petrography and mineral chemistry}

Greenschist and amphibolite facies mineral assemblages (M1-P, M1-A)

Metapelitic gneisses make up most of the crystalline basement in the Sierras de San Luis and outside the $\mathrm{CB}$ mylonite zone contain the mineral assemblage garnetbiotite-muscovite-plagioclase-quartz \pm staurolite \pm chlorite \pm sillimanite (M1-A, Table 1). The easternmost part of the $\mathrm{CB}$ is dominated by greenschist facies mineral assemblages as chlorite-biotite-muscovite-quartz-plagioclase-K-feldspar (M1-P, Table 1). The contact between M1-A and M1-P mineral assemblages is not completely clear but is in part sharp and in part a gradual change over a few km (von Gosen, 1998). Chlorite occurs in amphibolite facies M1-A and in phyllitic M1-P mineral assemblages as partly concordant, partly discordant grains relative to foliation. Staurolite is found only in the amphibolite facies M1-A mineral assemblages. The staurolites are observed mainly as idiomorphic 1 to $30 \mathrm{~mm}$ sized grains together with muscovite, biotite, and garnet (Fig. 3a) or as hypidiomorphic 5 to $30 \mathrm{~mm}$ sized grains which show intergrowth with fibrolitic sillimanite, quartz and plagioclase. In amphibolite facies M1-A metapelites, muscovite sometimes forms 


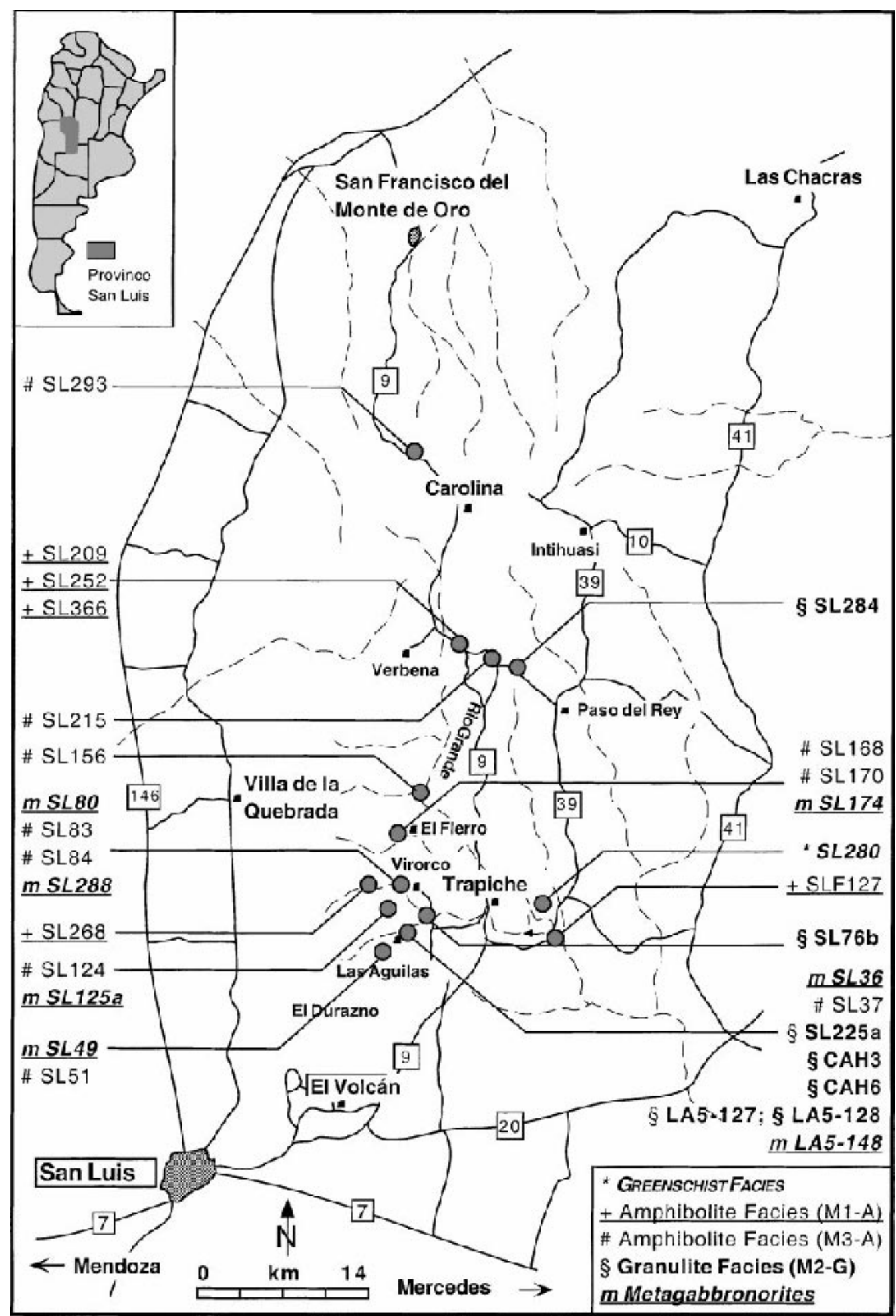

Fig. 2. Location map of samples used in this study. Different styles in letters indicate the different lithologies and/or metamorphic grade 
Table 1. Mineral assemblages from phyllites (M1-P) amphibolite and granulite facies rocks (M1-A; M2-G, M3-A), lower amphibolite facies mylonites (M3-Ph), metagabbrononites (MG) and calcsilicate rocks (CS) of the CB-block of the Sierras de San Luis

\begin{tabular}{|c|c|c|c|c|c|c|c|c|c|c|c|c|c|}
\hline Sample & Grt & $\mathrm{Bt}$ & Sta & Chl & Opx & $\mathrm{Sp}$ & Ms & Sil & Plg & Kfs & Qtz & $11 \mathrm{~m}$ & Rt \\
\hline \multicolumn{14}{|c|}{ Pelitic mineral assemblages } \\
\hline \multicolumn{14}{|c|}{ Greenschist facies mineral assemblage (M1-P) } \\
\hline SL280 & & $x$ & & $x$ & & & $x$ & & $\mathrm{x}$ & & $x$ & $x$ & \\
\hline \multicolumn{14}{|c|}{ Amphibolite facies mineral assemblage (M1-A) } \\
\hline SLF 127 & $x$ & $x$ & $x$ & $x$ & & & $x$ & & $x$ & & $x$ & & $x$ \\
\hline SL 209 & $x$ & $x$ & $x$ & $x$ & & & $x$ & $i$ & $x$ & & $x$ & $x$ & \\
\hline SL. 252 & & $x$ & $x$ & $x$ & & & $x$ & $x$ & $x$ & & $x$ & & \\
\hline SL 268 & $x$ & $x$ & & & & & $x$ & & $x$ & $x$ & $x$ & & \\
\hline SL 366 & & $x$ & & $x$ & & & $x$ & $x$ & $x$ & & $x$ & & \\
\hline \multicolumn{14}{|c|}{ Granulite facies mineral assemblage (M2-G) } \\
\hline SL 76b & $x$ & $x$ & & & & & & $x$ & $x$ & $x$ & $x$ & $x$ & $x$ \\
\hline SL 170 & $x$ & $x$ & & & & & & $x$ & $x$ & $x$ & $x$ & $x$ & $x$ \\
\hline SL 225a & $x$ & $x$ & & & & & & & $x$ & & $x$ & $x$ & \\
\hline $\mathrm{CAH} 3$ & $x$ & $x$ & & & $x$ & & & & $x$ & $x$ & $x$ & $x$ & $x$ \\
\hline $\mathrm{CAH} 6$ & $x$ & $x$ & & & & $i$ & $r$ & $x$ & $x$ & $x$ & $x$ & $x$ & $x$ \\
\hline LA5-127 & $x$ & $x$ & & & & & $r$ & $x$ & $x$ & $x$ & $x$ & $x$ & $x$ \\
\hline LA5-128 & $x$ & $x$ & & & & & & $x$ & $x$ & $x$ & $x$ & $x$ & $x$ \\
\hline
\end{tabular}

Amphibolite facies mineral assemblage (M3-A)

$\begin{array}{lll}\text { SL 37 } & x & x \\ \text { SL 51 } & x & x \\ \text { SL 84 } & x & x \\ \text { SL 106 } & x & x \\ \text { SL 156 } & x & x \\ \text { SL 168 } & x & x \\ \text { SL 215 } & x & x\end{array}$

Mylonite mineral assemblage (M3-Ph)

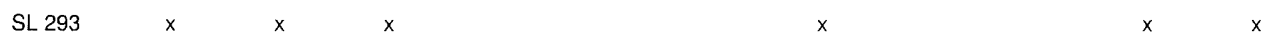

Amphibolite and granulite facies metagabbronorite mineral assemblage (MG)

\begin{tabular}{|c|c|c|c|c|c|c|c|c|c|c|c|c|c|}
\hline Sample & Grt & Opx & Cpx & $\mathrm{Ol}$ & $\mathrm{Bt}$ & $S p$ & $\mathrm{Hbl}$ & Ant & $\mathrm{Chl}$ & Plg & $\mathrm{llm}$ & Rt & Serp \\
\hline SL 36 & & $x$ & $x$ & & $x$ & & $x$ & $x$ & & $x$ & $x$ & & \\
\hline SL 49 & $x$ & & $x$ & & & & $x$ & & & $x$ & $x$ & & \\
\hline SL 80 & & $x$ & $x$ & & $x$ & & $x$ & & & $x$ & & $x$ & \\
\hline SL 125a & & $x$ & $x$ & & & $x$ & $x$ & & & $x$ & & & \\
\hline SL 174 & & $x$ & $x$ & & & & $x$ & & $r$ & $x$ & & & \\
\hline SL 288 & & $x$ & $x$ & & $x$ & $x$ & $x$ & & $r$ & $x$ & & & \\
\hline SL 137 & & $x$ & $x$ & & & & $x$ & & & $x$ & & & \\
\hline LA5-148 & & $x$ & $x$ & $x$ & & $x$ & $x$ & & & & & & $x$ \\
\hline LA5- 141 & & $x$ & $x$ & $x$ & & $x$ & $x$ & & & & & & $x$ \\
\hline
\end{tabular}

Granulite facies calcsilicate mineral assemblage (CS)

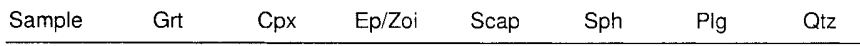

$\begin{array}{lllllllll}\text { SL } 284 & x & x & r & x & x & x & x\end{array}$

$x$ stable phase in mineral assemblage; $i$ inclusion in garnet or sillimanite; $r$ mineral formed during retrograde event 


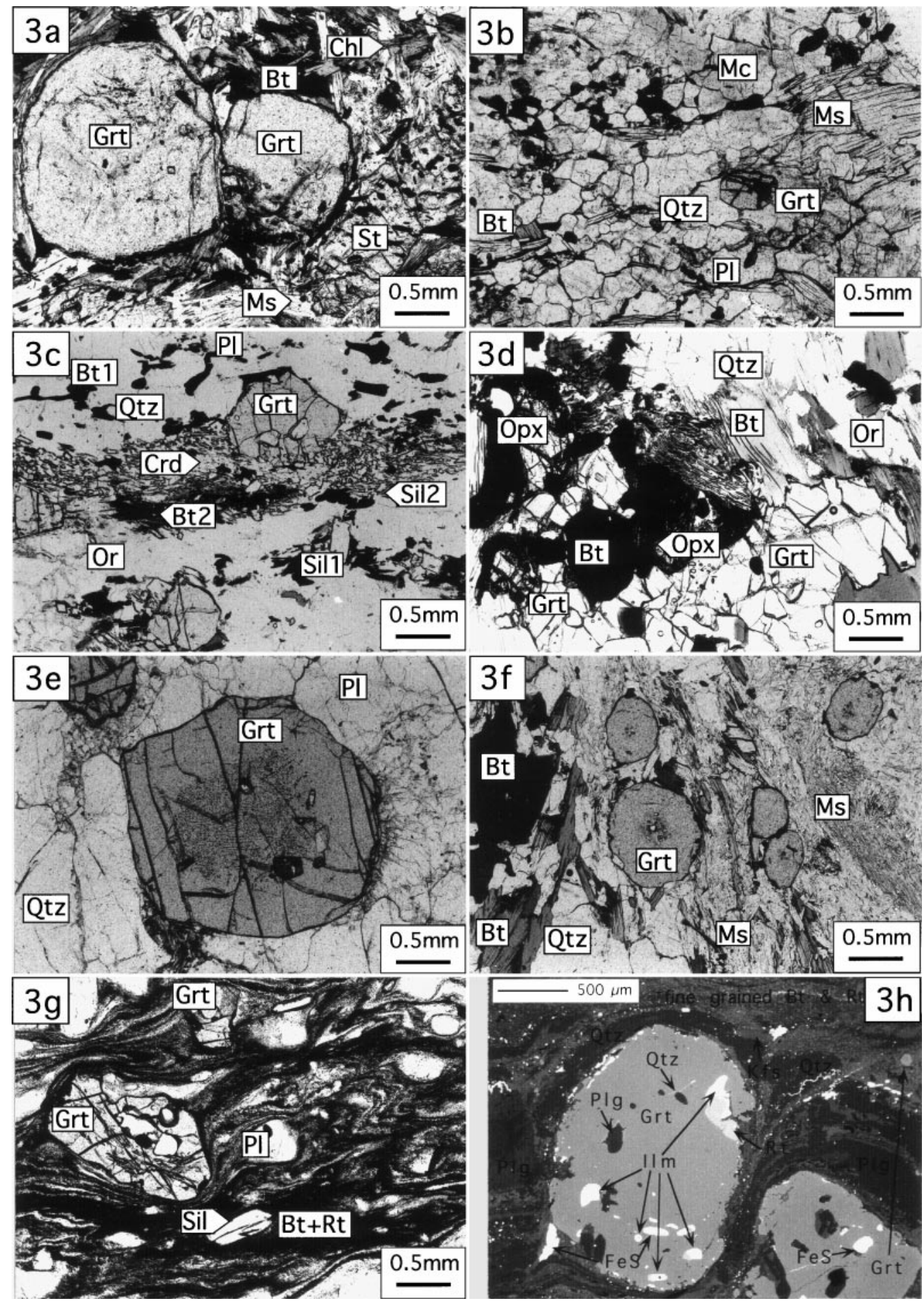

Fig. 3. a Photomicrograph of a $\mathrm{Grt}-\mathrm{St}-\mathrm{Chl}-\mathrm{Bt}-\mathrm{Ms}$ schist (M1-A) from the eastern part of the CB. St is full of inclusions of ilmenite (Ilm) and some rutile (Rt) $\mathbf{b}$ Photomicrograph of Grt-Ms-Bt schist (M1-A) from the western part of the CB. Muscovite (Ms) forms coarse-grained flakes within the equigranular matrix of quartz $(\mathrm{Qtz})$, plagioclase $(\mathrm{Pl})$, 
grains with about $1 \mathrm{~cm}$ in diameter, intergrown or in reaction texture with fibrolitic sillimanite. Phyllites and lower amphibolite facies mylonites commonly show deformed hypidomorphic plagioclase porphyroclasts and microcline. Plagioclase in phyllites is very albite-rich. The amphibolite facies rocks (M1-A) lack K-feldspar with only plagioclase, quartz, and micas forming the matrix. Garnet is usually found in all M1-A mineral assemblages as idiomorphic to subidiomorphic 0.1 to $5 \mathrm{~mm}$ sized grains. Sillimanite occurs as either needle-like inclusions in garnet or as fibrolite together with muscovite or staurolite.

\section{Granulite facies mineral assemblages $(M 2-G)$}

Within the $\mathrm{CB}$ mylonite zone relics of the granulite facies mineral assemblage cordierite-garnet-biotite-sillimanite-K-feldspar-plagioclase-quartz-ilmenite -rutile \pm orthopyroxene (M2-G, Table 1) can be found within undeformed domains of pelitic gneisses. Cordierite usually reacts to sillimanite and biotite and is altered along cracks (Fig. 3c). In some samples cordierite is absent in the matrix, but is still preserved as inclusions in garnet. Biotite is the only stable mica in the high grade granulite facies mineral assemblages (M2-G). In some samples biotite forms myrmekitic textures with quartz and feldspars probably due to incipient melting (Fig. 3d). Texturally and chemically two different generations of biotite can be identified (Fig. 3c): (1) large grains of matrix biotite with $\mathrm{TiO}_{2}$ contents of 5 to $6 \mathrm{wt} . \%$ and (2) small grains of reaction biotites which were formed together with a second sillimanite generation by the retrograde reaction:

$$
\text { Cordierite }+ \text { Garnet }=\text { Biotite }+ \text { Sillimanite }\left(+\mathrm{H}_{2} \mathrm{O} / \text { Melt }+ \text { Quartz }+ \text { K-feldspar }\right)
$$

This second biotite generation has a lower $\mathrm{TiO}_{2}$ of 2 to $3 \mathrm{wt} . \%$. Two different types of sillimanite are identified: (1) primary sillimanite seen as large prismatic grains (Fig. 3c, 3g), and (2) small prismatic sillimanite as product from reaction (1) in Fig. 3c. Orthopyroxene is very rarely observed in metapelites. It occurs with an

Fig. 3 (caption continued)

microcline $(\mathrm{Mc})$, garnet $(\mathrm{Grt})$ and biotite $(\mathrm{Bt}) \mathbf{c}$ Photomicrograph of the granulite facies (M2-G) Grt-Crd-Sil-Bt mineral assemblage. Cordierite (Crd) is reacting to a second generation of biotite $(\mathrm{Bt} 2)$ and sillimanite (Sil2) d Photomicrograph of a $\mathrm{Grt}-\mathrm{Opx}-\mathrm{Bt}$ gneiss (M2-G). Orthopyroxene (Opx) shows an alteration rim of anthophyllite. Biotite (Bt) occasionally is poikilitic indicative of incipient melting e Granulite facies prograde zoned garnet (M2-G) with an inclusion-rich core. A significant change in composition can only be seen in Ca (Fig. 4d) f Photomicrograph of a retrograded former migmatite (A2). Garnets (Grt) have quartz inclusions in their core but are homogeneous in composition (Fig. 4g) g Photomicrograph of a mylonite (M3-A). The strong deformation retrograded the $\mathrm{G}$ mineral assemblage to amphibolite facies conditions. The fine-grained matrix consists of recrystallized biotite $(\mathrm{Bt})$ and rutile $(\mathrm{Rt}) \mathbf{h}$ Back-scattered electron (BSE) image of garnet from a mylonite sample. Ilmenite (Ilm) is only stable as inclusion in garnet. Newly formed small garnets (upper right corner) are interpreted to have grown during deformation; their composition is similar to the retrograded rims of larger garnets 
C. A. Hauzenberger et al.
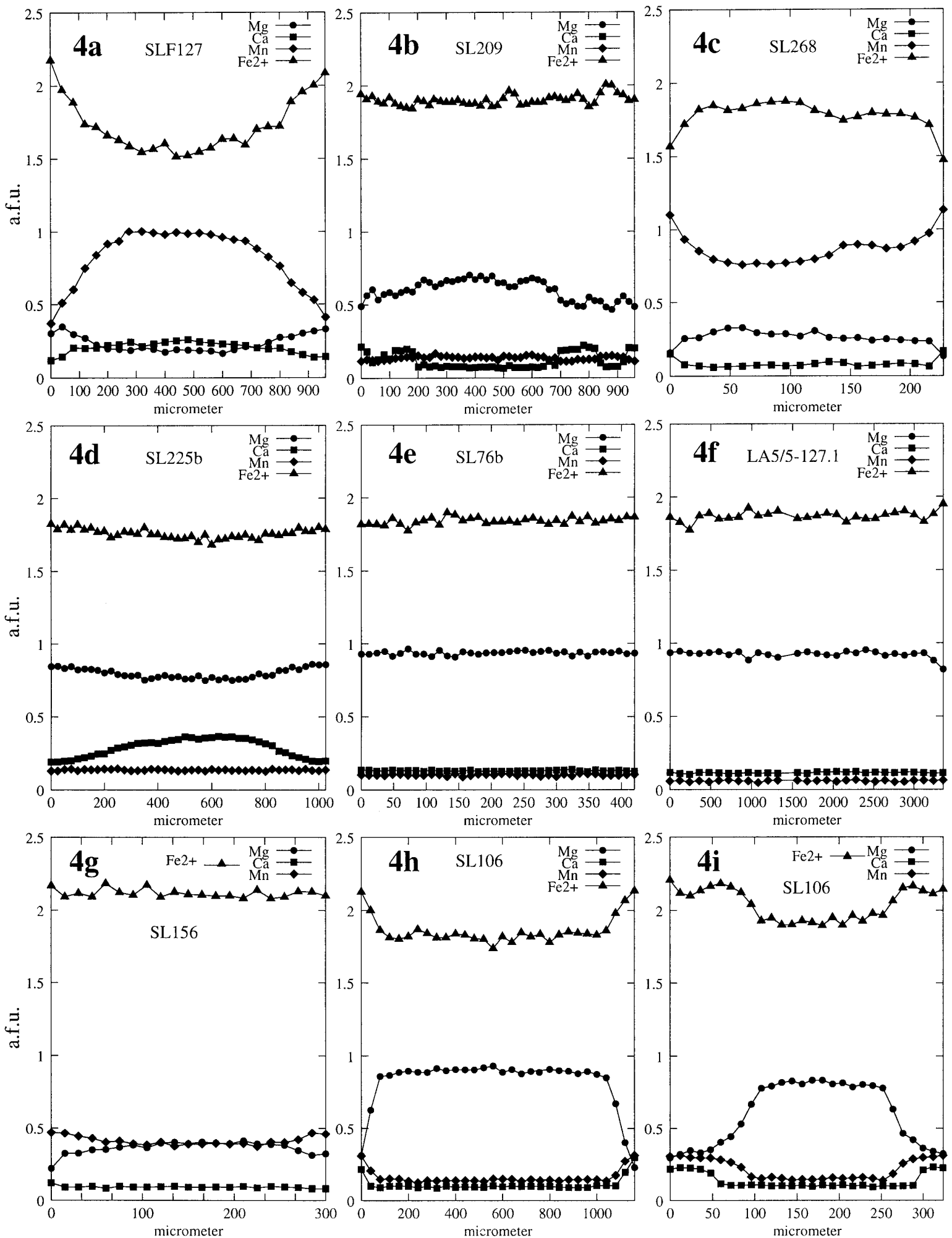

Fig. 4. Representative microprobe traverses: a Prograde zonation pattern of garnet of the first metamorphic event M1-A. A photomicrograph of this garnet is shown in Fig. $3 b$

(continued) 
alteration rim of amphibole together with garnet, biotite, and feldspars, lacking sillimanite and cordierite (Fig. 3d). Both, ilmenite and rutile are stable phases in most M2-G samples.

\section{Amphibolite facies mineral assemblages in mylonites (M3-A, M3-Ph)}

The overprinting amphibolite facies CB mylonitic mineral assemblage comprises garnet-biotite-muscovite-plagioclase-quartz-rutile (M3-A, Table 1) (Fig. 3f, 3g, 3h). Deformation of rocks leads in some cases to a completely fine grained recrystallization of biotite (Fig. 3g, 3h). In contrast to M2-G mineral assemblages, rutile is the only stable phase in the matrix. Ilmenite occurs as inclusion in garnet (Fig. 3h).

The lower amphibolite facies mylonite zone between the CB and WB (Fig. 1) consists of the mineral assemblage biotite-muscovite-quartz-plagioclase-Kfeldspar \pm garnet \pm chlorite (M3-Ph, Table 1).

\section{Amphibolite and granulite facies metagabbronorite mineral assemblage (MG)}

Mafic rocks are found as lenticular bodies up to several kilometers in length. They are normally less deformed than the basement and therefore the original magmatic texture is usually preserved (Fig. 5a). However, deformation linked to mylonitization can be observed in bent pyroxene crystals (Fig. 5c) and in reequilibrated mineral compositions consistent with amphibolite to granulite facies metamorphic grade. In some places amphibolite-migmatites can be observed.

Most of the rocks are gabbros or gabbronorites with mineral assemblages of orthopyroxene-clinopyroxene-amphibole-plagioclase \pm olivine \pm biotite (Table 1). Local ultramafic rocks contain abundant base metal sulfides (BMS) and Cr-Spinel (Table 1). Ortho- and Clinopyroxene are very common in mafic, locally ultramafic rocks. They occur mostly as idiomorphic to hypidiomorphic grains together with plagioclase and hornblende in the mafic part (Fig. 5a) and olivine and spinel in the

Fig. 4 (caption continued)

b Homogeneous zonation pattern of garnet from the northern part of the CB c Garnet zonation pattern showing retrograded rims from a sample from the western part of the CB (Fig. 3c) d Prograde zonation pattern of a garnet from the granulite facies rocks. The decrease of $\mathrm{Ca}$ from core to rim is interpreted as an isobaric $\mathrm{T}$ increase. The garnet is also optically zoned as can be seen in Fig. $3 \mathrm{f}$ e Homogeneous zonation pattern from garnet of a M2-G mineral assemblage from the Virorco area (Fig. 2) f Homogeneous garnet zonation pattern from a drillcore at Las Aguilas. The sample has been taken about $3 \mathrm{~m}$ from the contact to the mafic intrusion $\mathbf{g}$ Homogeneous garnet zonation pattern with a retrograded rim from a M3-A mineral assemblage. Although garnets are optically zoned (Fig. 3g) they are chemically homogeneous. Only at the rims $\mathrm{Mg}$ decreases and $\mathrm{Mn}$ increases which is interpreted as retrograde cooling effect $\mathbf{h}$ Zoned garnet from a M3-A mineral assemblage. The core preserves the former granulite facies composition, only newly grown rims show the lower A2 metamorphic conditions i Garnet from the same sample as $4 \mathrm{~h}$. The growth of garnet can be seen more clearly in this grain. Ca starts to increase closer to the rim than Fe, $\mathrm{Mn}$, and $\mathrm{Mg}$ 


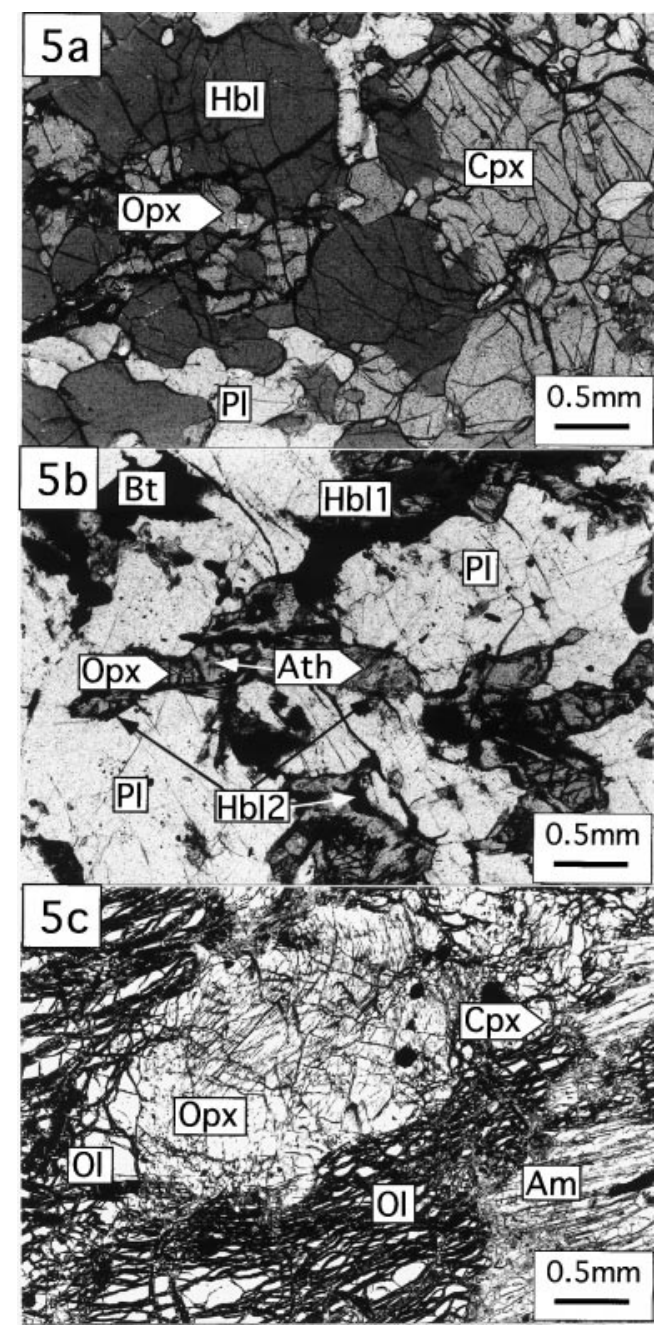

Fig. 5. a Photomicrograph of a gabbronorite from a mafic lens found at El Fierro (Fig. 2). The texture still looks magmatic but mineral compositions of hornblende ( $\mathrm{Hbl})$, orthopyroxene (Opx), and clinopyroxene (cpx) indicate reequilibration to amphibolite and granulite facies conditions b Photomicrograph showing reaction textures related to a metamorphic overprint. Orthopyroxene $(\mathrm{Opx})$ is altered to anthophyllite (Ath) which reacts with plagioclase $(\mathrm{Pl})$ to a second generation of hornblende (Hbl2) c Photomicrograph of an ultramafic part of the mafic intrusion. The metamorphic and tectonic overprint is shown by clinopyroxene (Cpx), which is partly replaced by amphibole (Am), and by bent orthopyroxene crystals. The clinopyroxene exsolution lamellae in orthopyroxene have been altered to amphibole. Olivine (Ol) has been slightly altered to serpentine

ultramafic part (Fig. 5c). Sometimes alteration of ortho- and clinopyroxene to hornblende, actinolite, or anthopyllite can be observed (Fig. 5b, 5c). The $\mathrm{X}_{\mathrm{Mg}}(\mathrm{Mg} /$ $(\mathrm{Mg}+\mathrm{Fe}+\mathrm{Mn}))$ of orthopyroxene varies from about 0.5 in gabbroic parts to 0.9 in the ultramafic cumulates. Olivine is only found in ultramafic parts together with pyroxenes, Cr-spinel, and BMS. Unlike orthopyroxene, olivine is slightly altered to serpentine and secondary magnetite. A typical texture can be seen in Fig. 5c. Crspinels have been encounterd mainly in the peridotitic part of the Las Aguilas body. They occur as disseminated rounded phases enclosed in olivine, ortho- and clinopyroxene phenocrysts, and BMS. Many of the Cr-spinel grains have been partly altered developing a rim of magnetite rich spinel (Table 3). Amphiboles occur in two texturally different generations: (1) Large grains of tschermakitic or magnesio-hornblende are normally gabbronorites and coexist in gabbronorites with orthopyroxene, clinopyroxene, plagioclase, and \pm biotite. However, lower grade alteration can be seen in these grains as patchy intergrowths of hornblende and tremolite/actinolite. (2) Secondary amphiboles are formed as alteration product of 
Table 2a. Representative electron microprobe analyses of muscovite (M1-P, M1-A, M3-A, M3-Ph), chlorite (M1-P, M1-A), and staurolite (M1-A)

\begin{tabular}{|c|c|c|c|c|c|c|c|c|}
\hline Sample: & $\mathrm{S} 280 \mathrm{~ms} 3$ & Slf127ms5 & Sl106ms1 & S293ms2 & S280chl1 & Slf127chl4 & Sl127st12 & S209ST1 \\
\hline Mineral: & Ms & Ms & Ms & Ms & $\mathrm{Chl}$ & Chl & St & St \\
\hline $\mathrm{SiO} 2$ & 48.23 & 47.72 & 47.11 & 48.88 & 24.77 & 24.17 & 28.53 & 28.44 \\
\hline $\mathrm{TiO} 2$ & 0.49 & 0.26 & 0.79 & 0.34 & 0.00 & 0.01 & 0.50 & 0.49 \\
\hline $\mathrm{Al} 2 \mathrm{O} 3$ & 32.78 & 34.38 & 35.21 & 30.30 & 21.26 & 21.71 & 54.95 & 53.50 \\
\hline $\mathrm{FeO}$ & 3.68 & 1.86 & 1.99 & 3.28 & 23.72 & 25.46 & 10.11 & 13.80 \\
\hline $\mathrm{MnO}$ & 0.00 & 0.03 & 0.09 & 0.01 & 0.95 & 0.28 & 0.30 & 0.00 \\
\hline $\mathrm{ZnO}$ & 0.00 & 0.00 & 0.00 & 0.00 & 0.00 & 0.00 & 1.79 & 0.30 \\
\hline $\mathrm{MgO}$ & 1.58 & 0.69 & 0.60 & 1.76 & 15.73 & 12.36 & 0.93 & 1.55 \\
\hline $\mathrm{CaO}$ & 0.07 & 0.00 & 0.00 & 0.00 & 0.01 & 0.04 & 0.00 & 0.00 \\
\hline $\mathrm{Na} 2 \mathrm{O}$ & 0.30 & 0.78 & 0.61 & 0.12 & 0.00 & 0.00 & 0.07 & 0.00 \\
\hline $\mathrm{K} 2 \mathrm{O}$ & 9.17 & 9.85 & 10.35 & 8.59 & 0.00 & 0.10 & 0.01 & 0.00 \\
\hline Total: & 96.30 & 95.57 & 96.76 & 93.28 & 86.44 & 84.13 & 97.19 & 98.07 \\
\hline $\mathrm{Si}$ & 3.180 & 3.157 & 3.094 & 3.300 & 2.643 & 2.669 & 7.880 & 7.780 \\
\hline $\mathrm{Ti}$ & 0.024 & 0.013 & 0.039 & 0.017 & 0.000 & 0.000 & 0.106 & 0.101 \\
\hline Al & 2.548 & 2.681 & 2.726 & 2.413 & 2.673 & 2.825 & 18.100 & 17.500 \\
\hline $\mathrm{Fe} 2$ & 0.203 & 0.103 & 0.110 & 0.185 & 2.116 & 2.351 & 2.399 & 3.260 \\
\hline $\mathrm{Fe} 3$ & 0.000 & 0.000 & 0.000 & 0.000 & 0.000 & 0.000 & 0.000 & 0.000 \\
\hline $\mathrm{Mn}$ & 0.000 & 0.002 & 0.005 & 0.001 & 0.086 & 0.026 & 0.073 & 0.000 \\
\hline $\mathrm{Zn}$ & 0.000 & 0.000 & 0.000 & 0.000 & 0.000 & 0.000 & 0.372 & 0.064 \\
\hline $\mathrm{Mg}$ & 0.155 & 0.068 & 0.059 & 0.177 & 2.502 & 2.034 & 0.394 & 0.655 \\
\hline $\mathrm{Ca}$ & 0.005 & 0.000 & 0.000 & 0.000 & 0.000 & 0.005 & 0.000 & 0.000 \\
\hline $\mathrm{Na}$ & 0.038 & 0.100 & 0.078 & 0.016 & 0.001 & 0.001 & 0.039 & 0.000 \\
\hline$\underline{K}$ & 0.772 & 0.831 & 0.867 & 0.740 & 0.000 & 0.014 & 0.004 & 0.000 \\
\hline Sum: & 6.925 & 6.955 & 6.977 & 6.849 & 10.021 & 9.925 & 29.367 & 29.360 \\
\hline $\mathrm{XMg}$ & 0.43 & 0.40 & 0.35 & 0.49 & 0.54 & 0.46 & 0.14 & 0.17 \\
\hline$X K$ & 0.95 & 0.89 & 0.92 & $0.98-$ & & - & - & - \\
\hline
\end{tabular}

Oxygen basis for recalculation of the analyses: Ms, 11, Chl, 14; St, 46

ortho- and clinopyroxene and can be found in all rock types. Amphibole is usually a tschermakitic/magnesio hornblende or actinolitic/tremolitic. Both amphibole generations have about the same chemical composition. Orthoamphibole (anthophyllite) is sometimes derived from alteration of orthopyroxene. Figure $5 \mathrm{~b}$ shows alteration of orthopyroxene to anthophyllite and subsequently to hornblende. The abundance of plagioclase can vary from a major mineral in gabbroic parts to a minor interstitial phase in ultramafic parts. The chemical composition varies from $70 \mathrm{~mol} . \%$ anorthite in the mafic to $100 \mathrm{~mol} . \%$ anorthite in the ultramafic part. Biotite occurs as small to medium sized grains, sometimes altered to chlorite. Garnet is usually not present in the mafic-ultramafic complex, with the exception of a contact to metapelites where a garnet-clinopyroxene-plagioclase-hornblende bearing assemblage has been identified. The almandine and grossular rich garnets form coronas around clinopyroxene (Table 3).

\section{Granulite facies calcsillicate mineral assemblage (CS)}

Calcsilicate rocks are limited to a very few outcrops as centimeter to meter scale bodies enclosed in the granulite facies part of the crystalline basement. The matrix 
Table 2b. Representative electron microprobe analyses of biotite (M1-P, M1-A, M2-G, M3-A, $M 3-P h)$

\begin{tabular}{|c|c|c|c|c|c|c|c|}
\hline Sample: & S280bt2 & Slf127bt7 & S293bt1 & La5bt2* & La5bt19** & Cha3bt5 & SI37bt12 \\
\hline $\mathrm{SiO} 2$ & 38.00 & 34.87 & 34.47 & 36.62 & 36.41 & 36.78 & 37.32 \\
\hline $\mathrm{TiO} 2$ & 1.76 & 1.88 & 2.30 & 3.89 & 5.85 & 5.38 & 2.93 \\
\hline $\mathrm{Al} 2 \mathrm{O} 3$ & 16.91 & 18.44 & 16.03 & 18.57 & 16.61 & 14.73 & 17.42 \\
\hline $\mathrm{FeO}$ & 17.30 & 20.80 & 23.20 & 13.21 & 14.20 & 14.32 & 10.62 \\
\hline $\mathrm{MnO}$ & 0.35 & 0.30 & 0.23 & 0.07 & 0.01 & 0.05 & 0.08 \\
\hline $\mathrm{MgO}$ & 11.96 & 8.50 & 5.59 & 13.09 & 12.05 & 15.10 & 15.38 \\
\hline $\mathrm{CaO}$ & 0.16 & 0.00 & 0.21 & 0.00 & 0.00 & 0.00 & 0.00 \\
\hline $\mathrm{Na} 2 \mathrm{O}$ & 0.08 & 0.15 & 3.32 & 0.30 & 0.00 & 0.13 & 0.26 \\
\hline$\underline{\mathrm{K} 2 \mathrm{O}}$ & 8.69 & 9.05 & 7.77 & 9.96 & 9.92 & 9.97 & 10.26 \\
\hline Total: & 95.22 & 93.99 & 93.12 & 95.71 & 95.05 & 96.46 & 94.27 \\
\hline $\mathrm{Si}$ & 2.844 & 2.713 & 2.766 & 2.700 & 2.722 & 2.721 & 2.763 \\
\hline $\mathrm{Ti}$ & 0.012 & 0.110 & 0.517 & 0.043 & 0.000 & 0.019 & 0.163 \\
\hline Al & 1.492 & 1.691 & 1.516 & 1.614 & 1.463 & 1.284 & 1.520 \\
\hline $\mathrm{Fe} 2$ & 1.083 & 1.353 & 1.557 & 0.815 & 0.888 & 0.886 & 0.658 \\
\hline $\mathrm{Mn}$ & 0.022 & 0.020 & 0.016 & 0.004 & 0.001 & 0.003 & 0.005 \\
\hline $\mathrm{Mg}$ & 1.335 & 0.986 & 0.669 & 1.439 & 1.343 & 1.665 & 1.698 \\
\hline $\mathrm{Ca}$ & 0.013 & 0.000 & 0.018 & 0.000 & 0.000 & 0.000 & 0.000 \\
\hline $\mathrm{Na}$ & 0.099 & 0.023 & 0.139 & 0.216 & 0.329 & 0.299 & 0.038 \\
\hline$\underline{K}$ & 0.830 & 0.898 & 0.796 & 0.937 & 0.946 & 0.941 & 0.969 \\
\hline Sum: & 7.730 & 7.794 & 7.994 & 7.768 & 7.692 & 7.818 & 7.813 \\
\hline $\mathrm{XMg}$ & 0.55 & 0.42 & 0.30 & 0.64 & 0.60 & 0.65 & 0.72 \\
\hline
\end{tabular}

$*$ = biotite from reaction textures; ${ }^{* *}=$ matrix biotite; Oxygen basis for recalculation of the analyses; Bt, 11

consists mainly of anorthite-rich plagioclase, without calcite or dolomite. In addition scapolite, clinopyroxene, grossular-rich garnet, quartz, titanite, and tremolite were identified (Table 1).

Representative electron microprobe analyses of all mineral assemblages are given in Table 2 .

\section{Garnet zonation patterns}

Gneisses and metapelitic rocks with the exception of phyllites are usually garnetbearing. Four different types of garnet, corresponding to the metamorphic grade of the rocks have been identified:

Type 1: in lower amphibolite facies mylonites (between CB and WB) 0.05$0.1 \mathrm{~mm}$ hypidiomorph $\mathrm{Mn}$ rich garnets together with muscovite and biotite (Table 2d, S1293gt (M3-Ph)).

Type 2: amphibolite facies M1-A mineral assemblages contain usually idiomorphic to subidiomorphic garnets of $0.1-5 \mathrm{~mm}$ in size (Fig. 3a, 3b) and are found together with muscovite, biotite, \pm staurolite and sillimanite. Sample Slf 127 
Table 2c. Representative electron microprobe analyses of feldspars

\begin{tabular}{|c|c|c|c|c|c|}
\hline Sample: & S280pl5 & SIf127plg16 & La5pl4 & S293kf6 & La5kf3 \\
\hline Mineral: & $\mathrm{PI}$ & $\mathrm{Pl}$ & $\mathrm{PI}$ & Kfs & Kfs \\
\hline $\mathrm{SiO} 2$ & 69.62 & 63.58 & 58.87 & 64.81 & 65.40 \\
\hline $\mathrm{TiO} 2$ & 0.02 & 0.00 & 0.02 & 0.25 & 0.18 \\
\hline $\mathrm{Al} 2 \mathrm{O} 3$ & 19.64 & 22.19 & 26.17 & 18.26 & 18.94 \\
\hline $\mathrm{Fe} 2 \mathrm{O}^{*}$ & 0.03 & 0.28 & 0.00 & 0.00 & 0.00 \\
\hline $\mathrm{MnO}$ & 0.00 & 0.03 & 0.04 & 0.05 & 0.00 \\
\hline $\mathrm{MgO}$ & 0.00 & 0.00 & 0.07 & 0.10 & 0.05 \\
\hline $\mathrm{CaO}$ & 0.19 & 3.58 & 7.35 & 0.00 & 0.08 \\
\hline $\mathrm{Na} 2 \mathrm{O}$ & 10.76 & 9.08 & 6.88 & 0.21 & 1.94 \\
\hline $\mathrm{K} 2 \mathrm{O}$ & 0.07 & 0.07 & 0.09 & 15.60 & 14.34 \\
\hline Total: & 100.33 & 98.81 & 99.49 & 99.28 & 100.93 \\
\hline $\mathrm{Si}$ & 3.015 & 2.835 & 2.634 & 3.004 & 2.977 \\
\hline $\mathrm{Ti}$ & 0.001 & 0.000 & 0.001 & 0.009 & 0.006 \\
\hline $\mathrm{Al}$ & 1.003 & 1.166 & 1.380 & 0.997 & 1.016 \\
\hline $\mathrm{Fe} 2$ & 0.000 & 0.000 & 0.000 & 0.000 & 0.000 \\
\hline $\mathrm{Fe} 3$ & 0.001 & 0.009 & 0.000 & 0.000 & 0.000 \\
\hline $\mathrm{Mn}$ & 0.000 & 0.001 & 0.002 & 0.002 & 0.000 \\
\hline $\mathrm{Mg}$ & 0.000 & 0.000 & 0.005 & 0.007 & 0.003 \\
\hline $\mathrm{Ca}$ & 0.009 & 0.171 & 0.352 & 0.000 & 0.004 \\
\hline $\mathrm{Na}$ & 0.904 & 0.785 & 0.597 & 0.019 & 0.171 \\
\hline$\underline{K}$ & 0.004 & 0.004 & 0.005 & 0.922 & 0.833 \\
\hline Sum: & 4.937 & 4.971 & 4.976 & 4.960 & 5.010 \\
\hline$X \mathrm{kf}$ & 0.00 & 0.00 & 0.01 & 0.98 & 0.83 \\
\hline Xalb & 0.99 & 0.82 & 0.63 & 0.02 & 0.17 \\
\hline Xan & 0.01 & 0.18 & 0.37 & 0.00 & 0.00 \\
\hline
\end{tabular}

* = analysed as $\mathrm{FeO}$; Oxygen basis for recalculation of the analyses; $\mathrm{Pl}$, 8; Kfs, 8

(Fig. 3a, 4a) contains idiomorphic garnets with a chemical zoning pattern consistent with prograde growth (Mn is decreasing, Fe and $\mathrm{Mg}$ increasing towards the rim). Sample S1 209 (Fig. 4b) is homogeneous. Sample Sl 268 (Fig. 3b, 4c) exhibits a zoning pattern consistent with retrograde exchange. Fe and $\mathrm{Mg}$ decrease, Mn increases towards the rim.

Type 3: garnets from the highest grade mineral assemblages (M2-G) are found as xenoblastic, 0.2 to $5 \mathrm{~mm}$ large grains. They occur together with sillimanite, cordierite, biotite, ilmenite, and rutile (Fig. 3d, 3e, 3f). The average $\mathrm{Mg} / \mathrm{Mg}+\mathrm{Fe}$ ratio is between 0.34 to 0.38 , grossular contents range from 4 to $8 \mathrm{~mol} \%$ and spessartine content is below $5 \mathrm{~mol} \%$ (Fig. $4 \mathrm{~d}-\mathrm{f}$ ). In a very few samples texturally and chemically zoned garnets show a $\mathrm{Ca}$ decrease from core to rim. (Fig. 3e, 4d).

Type 4: the granulite facies M2-G mineral assemblages are partly replaced by the amphibolite facies M3-A mineral assemblages. Cordierite and ilmenite have usually reacted with garnet and are consumed to form sillimanite, biotite and rutile 
Table 2d. Representative electron microprobe analyses of garnet from M1-A (Slf127, 209), M2-G Lla5gt, Cha3gt2), M3-A (Sl37gt16n), M1-Ph (293gt3) mineral assemblages

\begin{tabular}{|c|c|c|c|c|c|c|c|}
\hline Sample: & Slf127gt1-c & Slf127gt2-r & 209GT2 & $293 g t 3$ & S37gt16n & La5gt6 & Cha3gt2 \\
\hline $\mathrm{SiO} 2$ & 36.87 & 37.31 & 37.20 & 36.26 & 38.70 & 38.70 & 37.77 \\
\hline TiO2 & 0.11 & 0.00 & 0.00 & 0.05 & 0.00 & 0.00 & 0.00 \\
\hline $\mathrm{Al} 2 \mathrm{O} 3$ & 20.62 & 20.64 & 20.91 & 20.14 & 20.94 & 21.75 & 20.98 \\
\hline $\mathrm{FeO}$ & 23.24 & 30.31 & 34.59 & 21.91 & 29.50 & 28.94 & 27.93 \\
\hline $\mathrm{Fe} 2 \mathrm{O} 3$ & 0.00 & 0.00 & 0.00 & 0.00 & 0.00 & 0.00 & 0.00 \\
\hline $\mathrm{MnO}$ & 13.76 & 6.01 & 2.01 & 19.50 & 0.78 & 0.82 & 0.86 \\
\hline $\mathrm{MgO}$ & 1.37 & 2.64 & 2.90 & 0.89 & 8.53 & 8.75 & 8.24 \\
\hline $\mathrm{CaO}$ & 2.95 & 1.65 & 2.09 & 0.29 & 1.15 & 1.29 & 2.89 \\
\hline $\mathrm{Na} 2 \mathrm{O}$ & 0.09 & 0.07 & 0.00 & 0.02 & 0.00 & 0.00 & 0.00 \\
\hline $\mathrm{K} 2 \mathrm{O}$ & 0.05 & 0.00 & 0.00 & 0.00 & 0.00 & 0.06 & 0.01 \\
\hline Total: & 99.06 & 98.63 & 99.70 & 99.06 & 99.60 & 100.31 & 98.68 \\
\hline $\mathrm{Si}$ & 3.015 & 3.039 & 3.005 & 3.004 & 3.016 & 2.985 & 2.963 \\
\hline $\mathrm{Ti}$ & 0.007 & 0.000 & 0.000 & 0.003 & 0.000 & 0.000 & 0.000 \\
\hline$A l$ & 1.987 & 1.981 & 1.990 & 1.967 & 1.920 & 1.977 & 1.940 \\
\hline $\mathrm{Fe} 2$ & 1.589 & 2.065 & 2.336 & 1.497 & 1.877 & 1.807 & 1.697 \\
\hline $\mathrm{Fe} 3$ & 0.000 & 0.000 & 0.000 & 0.000 & 0.045 & 0.060 & 0.135 \\
\hline $\mathrm{Mn}$ & 0.953 & 0.415 & 0.137 & 1.369 & 0.050 & 0.054 & 0.057 \\
\hline $\mathrm{Mg}$ & 0.167 & 0.321 & 0.350 & 0.110 & 0.991 & 1.006 & 0.964 \\
\hline $\mathrm{Ca}$ & 0.258 & 0.144 & 0.181 & 0.026 & 0.096 & 0.107 & 0.243 \\
\hline $\mathrm{Na}$ & 0.015 & 0.011 & 0.000 & 0.003 & 0.000 & 0.000 & 0.000 \\
\hline K & 0.005 & 0.000 & 0.000 & 0.000 & 0.000 & 0.006 & 0.001 \\
\hline Sum: & 7.996 & 7.976 & 7.999 & 7.979 & 7.995 & 8.002 & 8.000 \\
\hline Xalm & 0.54 & 0.70 & 0.78 & 0.50 & 0.62 & 0.61 & 0.57 \\
\hline Xpyr & 0.06 & 0.11 & 0.12 & 0.04 & 0.33 & 0.34 & 0.33 \\
\hline Xgrs & 0.09 & 0.05 & 0.06 & 0.01 & 0.03 & 0.04 & 0.08 \\
\hline Xsps & 0.32 & 0.14 & 0.05 & 0.46 & 0.02 & 0.02 & 0.02 \\
\hline
\end{tabular}

Oxygen basis for recalculation of the analyses: Grt, 12

(Fig. 3f-h). Garnets are slightly zoned, as seen in a decrease in $\mathrm{Mg} /(\mathrm{Mg}+\mathrm{Fe})$ from core to rim of approximately 0.35 to 0.25 . Ca amd $\mathrm{Mn}$ are usually constant but an increase from core to rim by about 1 to $3 \mathrm{~mol}$. \% can be observed (Fig. $4 \mathrm{~g}-\mathrm{i}$ ). In the highly deformed mylonites newly grown garnets, $0.1-0.2 \mathrm{~mm}$ in diameter, have similar compositions to those of the retrograded granulite facies M2-G garnets (Fig. 4i). In sample Sl 106 the mylonitization probably caused mechanical destruction and transformation of large garnet grains to a cluster of smaller grains. The newly formed cluster still has the shape of the precurser grain. The garnet zonation pattern (Fig. 4h, 4i) is characterized by a newly grown Mg-poorer and Caricher rim at the edges of the small grains. The zonation pattern in Fig. 4h, 4i shows a relict homogenous core with an increase of $\mathrm{Fe}, \mathrm{Mn}$, and $\mathrm{Ca}$ and a decrease of $\mathrm{Mg}$ toward the rim. The $\mathrm{Mg} / \mathrm{Mg}+\mathrm{Fe}$ decreases from core to rim from about 0.35 to 0.15. Ca begins to increase at a point closer to the rim than $\mathrm{Fe}, \mathrm{Mg}$, and $\mathrm{Mn}$. 
Table 2e. Representative electron microprobe analyses of cordierite, orthopyroxene, ilmenite and scapolite

\begin{tabular}{|c|c|c|c|c|c|c|}
\hline Sample: & La5cd1 & Cha6cd14 & SL76cd9 & Cha3opx4 & La5ilm5 & SL284sc6 \\
\hline Mineral: & Crd & Crd & Crd & Opx & $\mathrm{IIm}$ & Scap \\
\hline $\mathrm{SiO} 2$ & 48.48 & 49.31 & 48.97 & 51.24 & 0.20 & 45.12 \\
\hline TiO2 & 0.08 & 0.03 & 0.03 & 0.13 & 52.73 & 0.00 \\
\hline $\mathrm{Al} 2 \mathrm{O} 3$ & 32.41 & 32.84 & 32.03 & 2.66 & 0.30 & 27.70 \\
\hline $\mathrm{FeO}$ & 5.43 & 4.63 & 5.45 & 24.12 & 45.33 & 0.00 \\
\hline $\mathrm{MnO}$ & 0.00 & 0.13 & 0.11 & 0.19 & 0.29 & 0.00 \\
\hline $\mathrm{MgO}$ & 10.35 & 11.39 & 10.18 & 21.67 & 0.17 & 0.08 \\
\hline $\mathrm{CaO}$ & 0.02 & 0.00 & 0.04 & 0.32 & 0.09 & 18.49 \\
\hline $\mathrm{Na} 2 \mathrm{O}$ & 0.13 & 0.13 & 0.11 & 0.00 & 0.00 & 2.67 \\
\hline $\mathrm{K} 2 \mathrm{O}$ & 0.00 & 0.00 & 0.00 & 0.00 & 0.00 & 0.14 \\
\hline$\underline{\mathrm{Cl}}$ & - & - & - & & - & 0.12 \\
\hline Total: & 96.90 & 98.46 & 96.92 & 100.33 & 99.11 & 94.32 \\
\hline $\mathrm{Si}$ & 5.000 & 4.990 & 5.040 & 1.907 & 0.005 & 6.960 \\
\hline $\mathrm{Ti}$ & 0.006 & 0.002 & 0.002 & 0.004 & 1.002 & 0.000 \\
\hline $\mathrm{Al}$ & 3.940 & 3.920 & 3.890 & 0.117 & 0.009 & 5.040 \\
\hline $\mathrm{Fe} 2$ & 0.469 & 0.392 & 0.469 & 0.688 & 0.958 & 0.000 \\
\hline $\mathrm{Fe} 3$ & 0.000 & 0.000 & 0.000 & 0.063 & 0.000 & 0.000 \\
\hline $\mathrm{Mn}$ & 0.000 & 0.011 & 0.010 & 0.006 & 0.006 & 0.000 \\
\hline $\mathrm{Mg}$ & 1.593 & 1.719 & 1.563 & 1.202 & 0.006 & 0.020 \\
\hline $\mathrm{Ca}$ & 0.002 & 0.000 & 0.004 & 0.013 & 0.002 & 3.060 \\
\hline $\mathrm{Na}$ & 0.026 & 0.026 & 0.020 & 0.000 & 0.000 & 0.800 \\
\hline K & 0.000 & 0.000 & 0.000 & 0.000 & 0.000 & 0.030 \\
\hline $\mathrm{Cl}$ & & & - & - & - & 0.030 \\
\hline Sum: & 11.036 & 11.060 & 10.998 & 4.000 & 1.988 & 15.940 \\
\hline $\mathrm{XMg}$ & 0.77 & 0.81 & 0.77 & 0.64 & - & $q A n=0.68$ \\
\hline
\end{tabular}

Oxygen basis for recalculation of the analyses: Crd, 8; Opx, 6; Ilm, 3; Cation basis for recalculation of $\mathrm{Scap}, \mathrm{Si}+\mathrm{Al}=12$

\section{Geothermobarometry}

Geothermobarometry has been applied to the different lithologies in the central block (CB) in order to construct a $P T$ path for the evolution of the area. To obtain peak temperatures, mineral core compositions have been used. Rim compositions tend to give lower $P T$ conditions due to retrograde effects but are important for reconstructing the cooling history of the basement. Geobarometers are usually less prone to reequilibration processes because they involve net transfer reactions, which have large changes in reaction volume. For calculating $P T$ pairs we used 


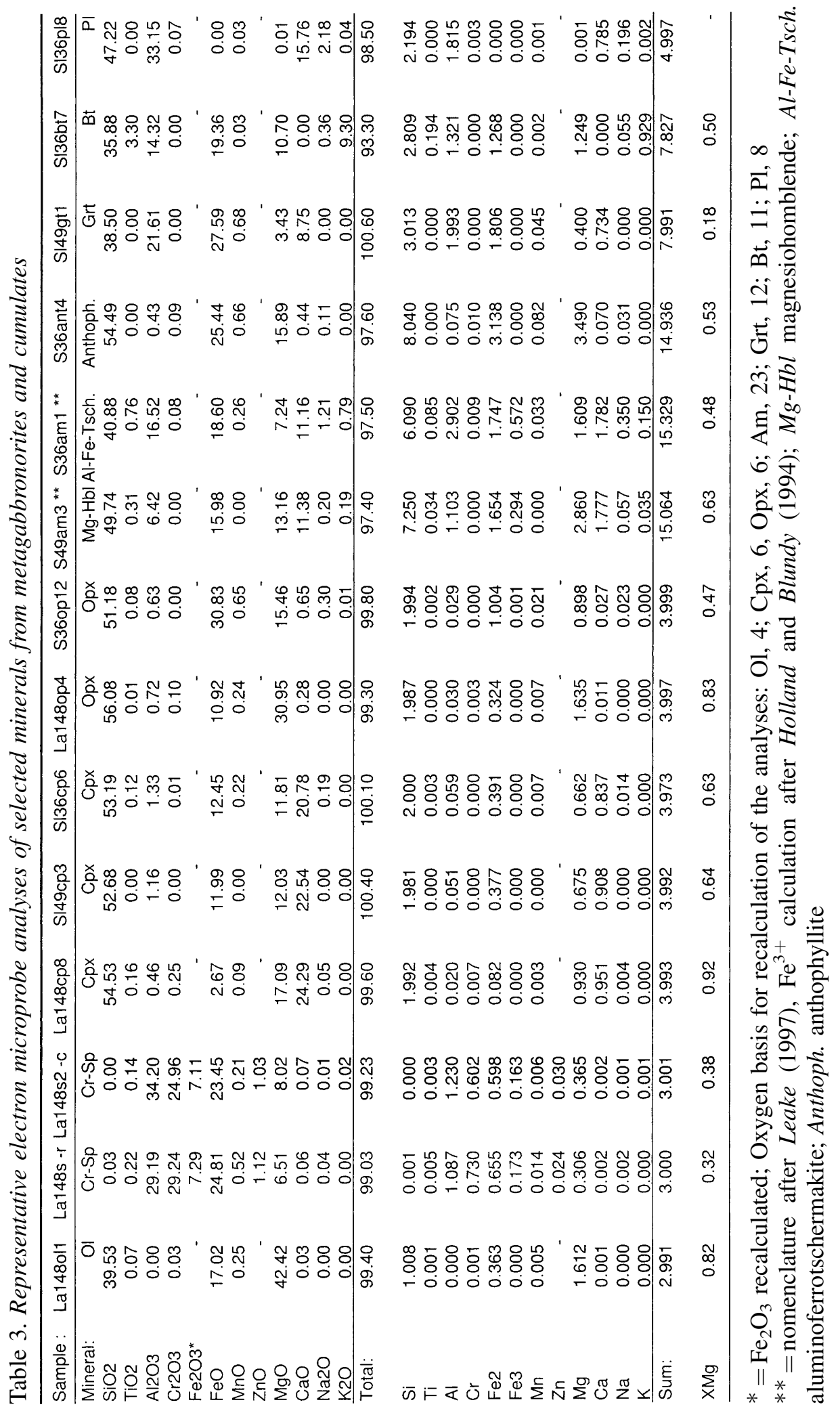


Table 4a. Geothermometric results of selected mineral pairs of representative samples of the basement area and intercalated metagabbronorites. Calculations of rim and core compositions are given where substantial chemical differences in minerals have been found

\begin{tabular}{|c|c|c|c|c|c|c|c|c|c|c|c|c|}
\hline Sample & Grt-Bt & $\mathrm{KD}$ & Grt-Crd & KD & Grt-Opx & KD & Grt-Sta & $\mathrm{KD}$ & Grt-Chl & $\mathrm{KD}$ & & \\
\hline \multicolumn{7}{|c|}{ Amphibolite facies mineral assemblage (M1-A) } & $=6 \mathrm{kbar}$ & & & & & \\
\hline SLF127 core & 550 & -1.95 & - & - & - & - & 565 & 0.45 & 540 & -2.11 & & \\
\hline SLF127 rim & 620 & -1.55 & - & - & - & - & - & - & 611 & -1.72 & & \\
\hline SL 209 & 535 & -2.05 & - & - & - & . & 605 & 0.29 & 540 & -2.11 & & \\
\hline SL 268 & 615 & -1.50 & - & - & - & - & - & - & - & - & & \\
\hline \multicolumn{7}{|c|}{ Granulite facies mineral assemblage (M2-G) } & $=7 \mathrm{kbar}$ & & & & & \\
\hline SL 76b & 755 & -1.06 & 730 & -1.88 & - & - & - & - & - & - & & \\
\hline SL 170 & 720 & -1.16 & - & - & - & - & - & - & - & - & & \\
\hline $\mathrm{CAH} 3$ & 770 & -1.20 & - & - & 730 & -1.12 & - & $\cdot$ & - & - & & \\
\hline $\mathrm{CAH} 6$ & 640 & -1.42 & 700 & -2.03 & - & - & - & - & - & - & & \\
\hline LA5-127 & 630 & -1.48 & - & - & - & - & - & - & - & - & & \\
\hline LA5-128 & 690 & -1.15 & 750 & -1.81 & - & - & - & - & - & - & & \\
\hline \multicolumn{7}{|c|}{ Amphibolite facies mineral assemblage (M3-A) } & $=6.5 \mathrm{kbar}$ & & & & & \\
\hline SL 37 & 660 & -1.31 & 695 & -2.06 & - & - & - & - & - & - & & \\
\hline SL 51 & 610 & -1.54 & - & - & - & - & - & - & - & - & & \\
\hline SL 84 & 680 & -1.42 & - & - & - & - & - & - & - & - & & \\
\hline SL 106 & 585 & -1.77 & - & - & - & - & - & - & - & - & & \\
\hline SL 156 & 620 & -1.50 & - & - & - & - & - & - & - & - & & \\
\hline SL 215 & 650 & -1.39 & - & - & - & - & . & - & - & - & & \\
\hline SL 293* & 555 & -1.77 & - & - & - & - & - & - & - & - & & \\
\hline Sample & Grt-Cpx & KD & Cpx-Opx & $\mathrm{KD}$ & Opx-Bt & KD & Ol-Cpx & KD & $\mathrm{Ol}-\mathrm{Sp}$ & $\mathrm{KD}$ & Amph-Plg & K \\
\hline \multicolumn{7}{|c|}{ Amphibolite and granulite facies metagabbronorite mineral assemblage (MG) } & $=7 \mathrm{kbar}$ & & & & & \\
\hline SL 36 core & . & - & 780 & -1.86 & 825 & 0.07 & - & - & - & - & 760 & -1.92 \\
\hline SL 36 rim & - & - & 740 & -2.07 & 740 & 0.20 & - & . & . & - & 675 & -1.23 \\
\hline SL 49 core & 690 & 2.09 & - & . & - & - & - & - & - & - & - & - \\
\hline SL 49 rim & 580 & 2.53 & - & - & - & - & - & - & - & - & 500 & -2.38 \\
\hline SL 174 core & - & - & 670 & -3.10 & - & - & - & - & - & - & - & - \\
\hline $\mathrm{SL} 174 \mathrm{rim}$ & - & - & 505 & -3.90 & . & - & - & - & - & - & - & - \\
\hline LA5-141 core & - & - & 825 & -2.54 & - & - & 770 & -2.10 & 745 & 2.10 & - & - \\
\hline LA5-141 rim & - & - & 705 & -3.01 & - & - & 645 & -1.61 & 660 & 2.69 & - & - \\
\hline LA5-148 core & - & - & 785 & -2.71 & - & - & 790 & -1.70 & 745 & 1.96 & - & - \\
\hline LA5-148 rim & - & - & 695 & -3.07 & - & - & 545 & -1.51 & 710 & 2.21 & - & - \\
\hline
\end{tabular}

Galibrations: Grt-Bt: Kleemann and Reinhardt (1994); Grt-Crd: Bhattacharya et al. (1988); Grt-Opx: Lal (1993); Grt-Sta: Perchuk (1991); Grt-Chl: Perchuk (1991); Grt-Cpx: Berman et al. (1995); Cpx-Opx: Brey and Koehler (1990); Opx-Bt: Sengupta et al. (1990); Ol-Cpx: Powell and Powell (1974); Ol-Sp: Ballhaus et al. (1991); Amph-Plg: Holland and Blundy (1994)

* Mylonite mineral assemblage $(\mathrm{Ph})$, thermometer $\mathrm{P}=6 \mathrm{kbar}$

only thermometers and barometers where phases belonged texturally to the same mineral assemblage and are thought to be in equilibrium.

For the quantification of peak metamorphic temperatures in amphibolite facies M1-A, M3-A, M3-Ph, and granulite facies M2-G metapelitic assemblages several $\mathrm{Mg}$ and $\mathrm{Fe}^{2+}$ exchange thermometers have been applied. The equilibria applied to metapelites and gneisses are summarized in Table 4a.

The temperatures for the amphibolite facies M1-A mineral assemblage are well constrained between $535-635{ }^{\circ} \mathrm{C}$ at $6 \mathrm{kbar}$ by garnet-biotite, garnet-chlorite, and garnet-staurolite thermometers. The garnet-biotite, garnet-cordierite, garnet-othopyroxene, biotite-orthopyroxene thermometers have been applied to M2-G mineral 
Table 4b. Geobarometric results of selected mineral pairs of representative samples of the basement area

\begin{tabular}{|c|c|c|c|c|c|}
\hline Sample & GASP & GRAIL & GAES & Grt-Plg-Ms-Bt & Grt-Plg-Ms \\
\hline \multicolumn{4}{|c|}{ Amphibolite facies mineral assemblage (M1-A) } & $\mathrm{T}=600^{\circ} \mathrm{C}$ & \\
\hline SLF127 c & - & - & - & 6.50 & - \\
\hline SLF127 r & - & - & - & 7.60 & \\
\hline SL 209 & 6.80 & - & - & 5.10 & 5.60 \\
\hline SL 268 & 5.60 & - & - & - & 6.40 \\
\hline \multicolumn{4}{|c|}{ Granulite facies mineral assemblage (M2-G) } & $\mathrm{T}=750^{\circ} \mathrm{C}$ & \\
\hline SL 76b & 7.00 & 7.20 & - & - & - \\
\hline SL 170 & 7.40 & - & - & - & - \\
\hline $\mathrm{CAH} 3$ & - & - & 6.9 & - & - \\
\hline $\mathrm{CAH} 6$ & 6.50 & 7.30 & - & - & - \\
\hline LA5-127 & 6.90 & 6.20 & - & & \\
\hline LA5-128 & 7.00 & 7.00 & - & - & - \\
\hline \multicolumn{4}{|c|}{ Amphibolite facies mineral assemblage (M3-A) } & $\mathrm{T}=650^{\circ} \mathrm{C}$ & \\
\hline SL 37 & 5.90 & 7.20 & - & - & - \\
\hline SL 51 & 7.40 & - & - & - & - \\
\hline SL 84 & 8.20 & - & - & - & - \\
\hline SL 106 & 6.70 & 7.00 & - & 5.10 & - \\
\hline SL 156 & - & - & - & - & - \\
\hline SL 215 & 5.20 & - & - & - & - \\
\hline SL $293^{*}$ & - & - & - & - & - \\
\hline
\end{tabular}

Calibrations: GASP: Koziol (1989); GRAIL, GAES: Bohlen et al. (1983); GrtPlg-Ms-Bt \& Grt-Plg-Ms: Hoisch (1990)

assemblages. Temperatures of $630-770^{\circ} \mathrm{C}$ at $7 \mathrm{kbar}$ were obtained (Table $4 \mathrm{a}$ ) from tectonically undeformed rocks. Figure $3 \mathrm{c}$ and $3 \mathrm{~d}$ show thin sections of this primary, almost unaltered M2-G mineral assemblage. For the M3-A mineral assemblages garnet-biotite thermometers yield temperatures of $555^{\circ} \mathrm{C}$ to $690^{\circ} \mathrm{C}$ at $6.5 \mathrm{kbar}$ with an average of most samples around $630^{\circ} \mathrm{C}$.

Several geothermometers have also been applied to the intercalated mafic rocks. Garnet-clinopyroxene, clino-orthopyroxene, orthopyroxene-biotite, olivine-clinopyroxene, spinel-olivine, and amphibole-plagioclase pairs yield temperatures of about $500^{\circ} \mathrm{C}$ to $825^{\circ} \mathrm{C}$ at $\mathrm{P}=7 \mathrm{kbar}$. The thermometers used for constraining temperatures in gabbronoritic rocks are listed in Table 4a.

In M1-A and M3-A rocks the mineral assemblage garnet-biotite-muscoviteplagioclase-quartz has been used for geobarometry.

$$
\text { Almandine }+ \text { Grossular }+ \text { Muscovite }=3 \text { Anorthite }+ \text { Biotite }
$$

$$
\text { Almandine }+2 \text { Grossular }+3 \mathrm{Al}_{2} \mathrm{Fe}_{-1} \mathrm{Si}_{-1} \text { (in Ms) }+6 \text { Quartz }=6 \text { Anorthite }
$$

Reaction 2 and 3 give results of 5.1 to $7.6 \mathrm{kbar}$ at $600^{\circ} \mathrm{C}$ for $\mathrm{M} 1-\mathrm{A}$ mineral assemblages and reaction 3 yields $5.1 \mathrm{kbar}$ at $650{ }^{\circ} \mathrm{C}$ for $\mathrm{M} 3-\mathrm{A}$ rocks. The geo- 
barometer garnet-sillimanite-quartz-anorthite (GASP) could be applied to M1-A, M2-G, and M3-A rocks from the Sierras de San Luis.

Samples from the M1-A mineral assemblage give pressures from about $5.6 \mathrm{kbar}$ to $6.8 \mathrm{kbar}$ at $600^{\circ} \mathrm{C}$. M3-A samples give pressures between $5.2 \mathrm{kbar}$ and $8.2 \mathrm{kbar}$ at $650{ }^{\circ} \mathrm{C}, \mathrm{M} 2-\mathrm{G}$ mineral assemblages between $6.5 \mathrm{kbar}$ and $7.4 \mathrm{kbar}$ at $\mathrm{T}=750^{\circ} \mathrm{C}$. In granulite facies rocks the presence of rutile, ilmenite and orthopyroxene facilitate use of the garnet-rutile-ilmenite-sillimanite-quartz (GRAIL) and the garnet-quartzanorthite-enstatite (GAES) barometers. They yield pressures of about $6.2 \mathrm{kbar}$ to $7.3 \mathrm{kbar}$ at $750^{\circ} \mathrm{C}$ (Table $4 \mathrm{~b}$ ).

\section{Discussion of geothermobarometry}

Results of all applied geothermometers and geobarometers are listed in Tables 4a and $4 \mathrm{~b}$, respectively. Garnet-biotite thermometry yields a large variation in temperatures, probably due to partial reequilibration during cooling. In order to overcome retrograde disequilibrium effects, chemical compositions from large garnet cores and biotite, which is far more abundant than garnet, have been used. Garnet line scans (Fig. 4) show that core compositions might not have reequilibrated during cooling. The high modal content of biotite assures that the composition of this mineral is only changed marginally.

Garnet-cordierite pairs in relatively fresh rocks are supposed to give temperature estimates closer to peak metamorphic conditions. However, the lower calculated temperature $\left(700^{\circ} \mathrm{C}\right.$, Table $\left.4 \mathrm{a}\right)$ is a result of resetting. The ability of cordierite to host $\mathrm{Na}$ in channels parallel to the c-axis is considered to be controlled by temperature making it a potential thermometer (Mirwald, 1986). Cordierites from the Sierras de San Luis contain typically around 0.10 to 0.20 wt. $\% \mathrm{Na}_{2} \mathrm{O}$ which would indicate temperatures of $750{ }^{\circ} \mathrm{C}$ to $800^{\circ} \mathrm{C}$, slightly higher than $\mathrm{T}$ calculated by $\mathrm{Mg}-\mathrm{Fe}^{2+}$ ion exchange. Orthopyroxene has only been observed in one sample where it shows alteration rims (Fig. 3d). The calculated temperature of the garnet-orthopyroxene thermometer of $730^{\circ} \mathrm{C}$ is slightly lower than from garnetcordierite.

The relatively large variability in temperature of M3-A mineral assemblages can be explained by different effects of the retrograde overprint during mylonitization and cooling from granulite facies conditions. Although cordierite forms part of the granulite facies M2-G mineral assemblage, amphibolite facies M3-A samples may carry cordierite relics. The temperature of $695^{\circ} \mathrm{C}$ is close to the lower values obtained in granulite facies rocks.

In mafic rocks from intrusive bodies, cation exchange- and solvus-thermometers give temperatures significantly lower than typical intrusion temperatures of $1100^{\circ} \mathrm{C}$ to $1200^{\circ} \mathrm{C}$. These relatively low temperatures are in very good agreement with the temperatures deduced from the metasedimentary units and are considered to have been retrograded during cooling and with the M3-A overprint. The higher temperatures of around $800{ }^{\circ} \mathrm{C}$ mark the peak of the $\mathrm{M} 2-\mathrm{G}$ granulite facies rocks and are found in mainly undeformed rocks, whereas temperatures low as $500{ }^{\circ} \mathrm{C}$ are from deformed, recrystallized, or altered rocks (M3-A) (Fig. 5b,c).

Pressures have been calculated for all 3 metamorphic mineral assemblages (M1-A, M2-G, M3-A) at the corresponding peak temperatures. The combination of 
a geothermometer and geobarometer should reveal the correct $P T$ conditions if both equilibrated at the same time. For M1-A mineral assemblages at $\mathrm{T}=600^{\circ} \mathrm{C}$, pressures of 5.1 to $7.6 \mathrm{kbar}$ with a mean around $6 \mathrm{kbar}$ could be calculated. The $\mathrm{M} 2-\mathrm{G}$ rocks show pressures at $\mathrm{T}=750{ }^{\circ} \mathrm{C}$ from 6.2 to $7.4 \mathrm{kbar}$ with a mean around $7 \mathrm{kbar}$. M3-A mineral assemblages show the largest spread in pressures at $\mathrm{T}=650{ }^{\circ} \mathrm{C}$ ranging from 5.2 to $8.2 \mathrm{kbar}$. The overprint of the $\mathrm{M} 2-\mathrm{G}$ mineral assemblage to M3-A might have lead to some of these disequilibrium effects.

\section{Petrogenetic grids}

As shown in the geothermobarometry section, the calculated PT conditions of the mineral assemblages M1, M2, and M3 are probably not sufficiently exact to construct a precise $P T$ path. In order to determine the $P T$ conditions more accurately a petrogenetic grid for the chemical system TKFMASH, describing the low variance M2-G mineral assemblage, has been calculated. Granulite facies rocks typically show incipient melting (migmatites). In order to construct a correct phase diagram the phase melt has to be considered as shown in experimentally derived phase diagrams by Carrington and Harley (1996). Thermodynamic data for melts are not yet of the same quality as for most minerals and therefore the melt phase was not considered in our calculations (see also figure caption of Fig. 7).

Most reactions involve a fluid phase. Quantification of $\mathrm{P}$ and $\mathrm{T}$ is thus of utmost importance to constrain the composition of this fluid. Fluid inclusions and thermodynamic calculations in the $\mu_{\mathrm{H}_{2} \mathrm{O}}$-T space of fluid involving mineral reactions can help to obtain fluid compositions. For calculations the program VERTEX, which was designed to compute phase diagrams for all possible compositions of a thermodynamic system (Connolly and Kerrick, 1987; Connolly, 1990), and the internally consistent database from Berman (1992) was used (Fig. 6). The observed cordierite + garnet $=$ biotite + sillimanite reaction involves a fluid phase and is therefore sensitive to fluid composition. The reactions

$$
\begin{array}{r}
\text { cordierite }+ \text { garnet }+ \text { sanidine }+\mathrm{H}_{2} \mathrm{O}=\text { biotite }+ \text { sillimanite }+ \text { quartz } \\
\text { biotite }+ \text { garnet }+ \text { quartz }=\text { cordierite }+ \text { orthopyroxene }+ \text { sanidine }+\mathrm{H}_{2} \mathrm{O}
\end{array}
$$

define a field which indicates possible water activities for $\mathrm{M} 2-\mathrm{G}$ rocks. Assuming a peak temperature of about $800^{\circ} \mathrm{C}$, a $\mathrm{H}_{2} \mathrm{O}-\mathrm{CO}_{2}$ fluid, and a fluid pressure equal to total pressure the water activity must have been equivalent to a $\mathrm{X}_{\mathrm{H}_{2} \mathrm{O}}$ of $0.2-0.5$ (Fig. 6). Even if the dilutant phase is not $\mathrm{CO}_{2}$, the effect on the $\mathrm{H}_{2} \mathrm{O}$ activity should be very similar. Evidence for these relatively low water activities can also be found in $\mathrm{CO}_{2}$-rich-fluid inclusions in quartz, sillimanite, cordierite, and garnet.

Several petrogenetic grids for granulite facies rocks have been constructed in recent years (Harley, 1989; Stüwe and Powell, 1989; Spear and Cheney, 1989; Hand et al., 1994, Carrington and Harley, 1996). Most of them have been either qualitatively showing the topological relations between reactions, did not account for solid solution phases, or were drawn for $\mathrm{X}_{\mathrm{H}_{2} \mathrm{O}}=1$. As discussed in the geothermobarometry section, reequilibration processes may add large errors in specifying $P T$ conditions. A $P T$ diagram with computed theoretical compositions of solid solutions of minerals, which are dependent on the used thermodynamic database and solution models, has been calculated with VERTEX and the database 


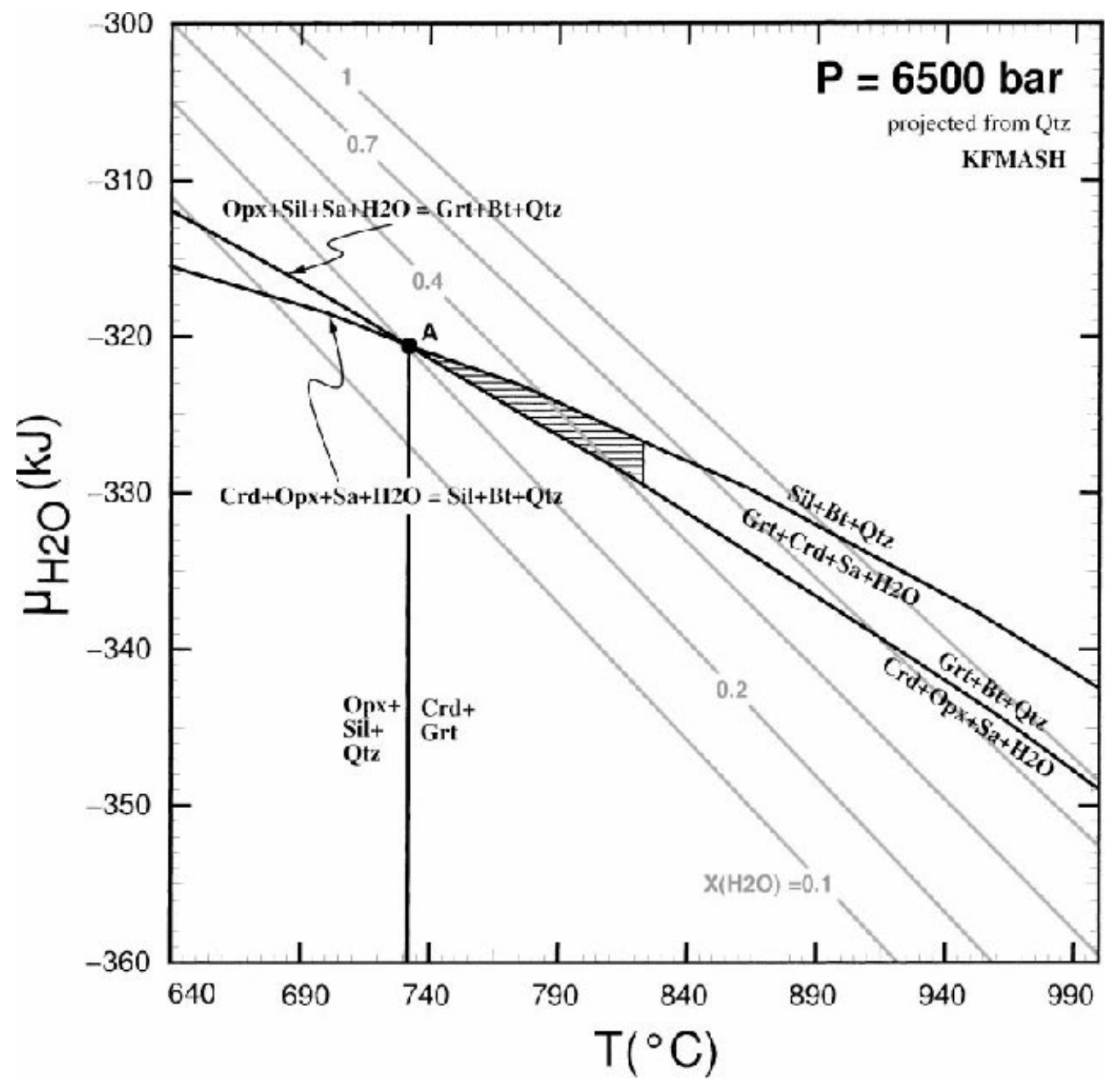

Fig. 6. A T $-\mu_{\mathrm{H}_{2} \mathrm{O}}$ diagram has been used for the calculation of $\mathrm{X}_{\mathrm{H}_{2} \mathrm{O}}$ at granulite facies conditions. The reactions $\mathrm{Grt}+\mathrm{Crd}+\mathrm{Sa}+\mathrm{H}_{2} \mathrm{O}=\mathrm{Bt}+\mathrm{Sil}+\mathrm{Qrz}$ and $\mathrm{Crd}+\mathrm{Opx}+\mathrm{Sa}+\mathrm{H}_{2} \mathrm{O}=$ $\mathrm{Bt}+\mathrm{Grt}+\mathrm{Qtz}$ enclose a field of possible $\mathrm{X}_{\mathrm{H}_{2} \mathrm{O}}$ compositions. The $\mathrm{X}_{\mathrm{H}_{2} \mathrm{O}}$ lines are valid if fluid pressure equals total pressure and $\mathrm{CO}_{2}$ and $\mathrm{H}_{2} \mathrm{O}$ are the only species in the fluid phase. The calculated $\mathrm{X}_{\mathrm{H}_{2} \mathrm{O}}$ of the fluid phase is between 0.2 and 0.5. For the calculation of the PT diagram shown in Fig. 7, a value of 0.4 has been used

of Berman (1992) (Fig. 7). The calculated reactions and the corresponding chemical compositions of minerals are compared to the actual analyzed mineral compositions. By using this method, which computes the chemical composition of the stable mineral assemblage according to the used solution model, we would immediately notice if one phase, e.g. biotite, is not in equilibrium. For the quantification of $P T$ conditions of the granulite facies mineral assemblage (M2-G) and exhumation history, the chemical system TKFMASH has been chosen and the following phases have been used for calculation: garnet-cordierite-orthopyroxene - spinel-biotite - sillimanite - kyanite - andalusite - muscovite-sanidine-quartz- 


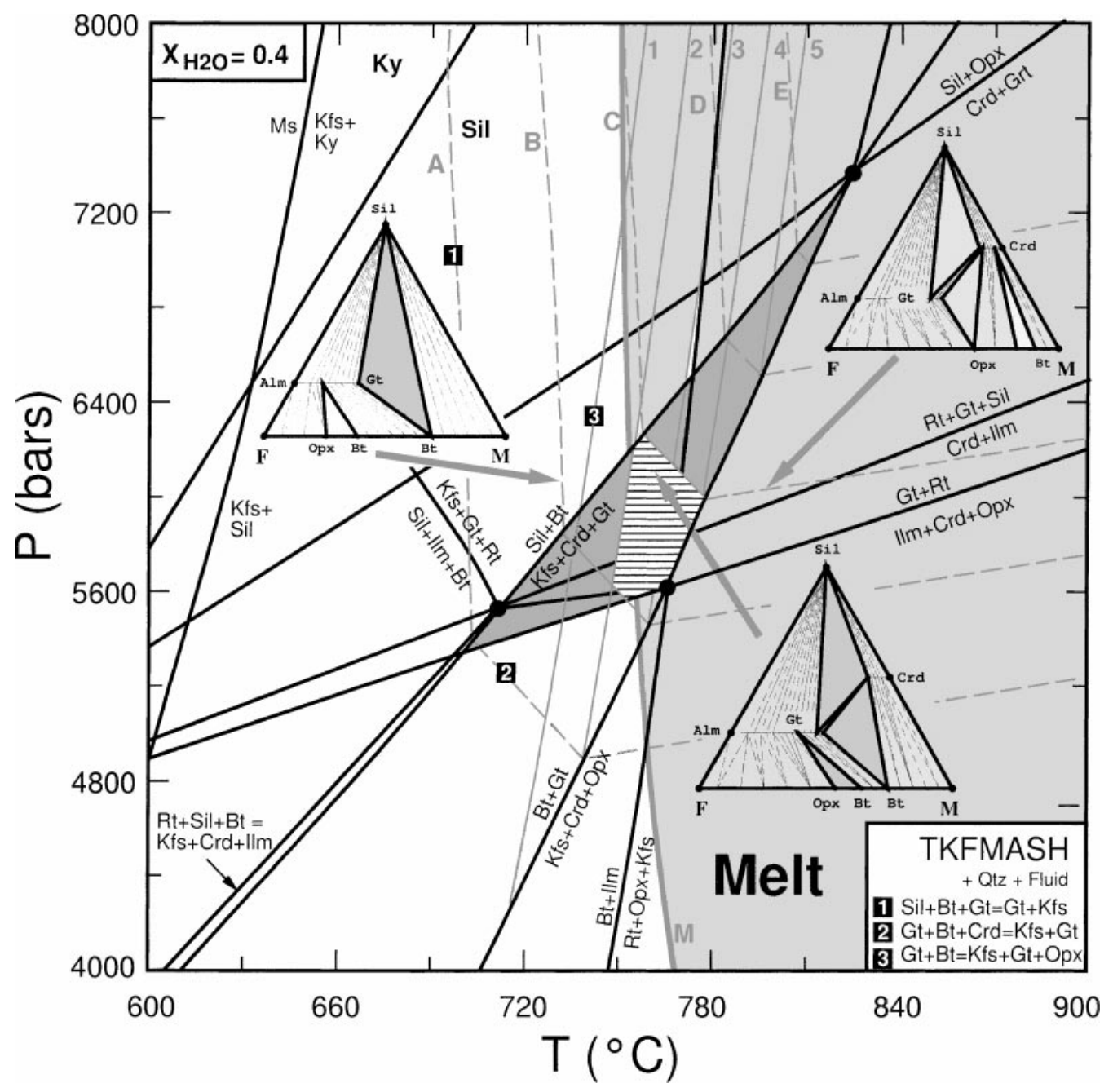

Fig. 7. Calculated PT-diagram using the thermodynamic database of Berman (1992), ideal solution models for biotite, cordierite, and orthopyroxene and a nonideal solution model for garnet (Berman, 1990). The reactions $\mathrm{Bt}+\mathrm{Sil}+\mathrm{Qtz}=\mathrm{Grt}+\mathrm{Crd}+\mathrm{Sa}+\mathrm{H}_{2} \mathrm{O}$ and $\mathrm{Bt}+\mathrm{Grt}+\mathrm{Qtz}$ $=\mathrm{Crd}+\mathrm{Opx}+\mathrm{Sa}+\mathrm{H}_{2} \mathrm{O}$ are limiting a field of peak metamorphic conditions for the granulite facies mineral assemblage $\mathrm{M} 2-\mathrm{G}$ between $700^{\circ} \mathrm{C}$ and $800^{\circ} \mathrm{C}$ at $\mathrm{X}_{\mathrm{H}_{2} \mathrm{O}}=0.4$. The small box within the dark gray area indicates the $P T$ range $\left(740-790^{\circ} \mathrm{C}\right.$ and $\left.5.7-6.4 \mathrm{kbar}\right)$ obtained by comparing calculated chemical compositions of Crd, Bt, Opx, and Grt with analyzed chemical compositions (Table 2). The granite melt solidus for $\mathrm{X}_{\mathrm{H}_{2} \mathrm{O}}$ (Johannes and Holtz, 1996) is shown as thick gray line (M). The phase melt has not been considered in calculations, therefore mineral reactions lying in the melt present area (in light gray) are metastable. A, B, C, D, E, 1, 2, 3, 4, 5 label isopleths of constant Grt, Bt, Crd, and Opx composition $\quad\left(\mathbf{A}=\mathrm{Bt} \quad\left(\mathrm{X}_{\mathrm{Mg}}=0.72\right), \quad \mathrm{Gt} \quad\left(\mathrm{X}_{\mathrm{Mg}}=0.32\right), \quad \mathrm{Crd} \quad\left(\mathrm{X}_{\mathrm{Mg}}=0.74\right) ; \quad \mathbf{B}=\mathrm{Bt}\right.$ $\left(\mathrm{X}_{\mathrm{Mg}}=0.72\right), \mathrm{Gt}\left(\mathrm{X}_{\mathrm{Mg}}=0.38\right), \mathrm{Crd}\left(\mathrm{X}_{\mathrm{Mg}}=0.74\right) ; \mathbf{C}=\mathrm{Bt}\left(\mathrm{X}_{\mathrm{Mg}}=0.80\right), \mathrm{Gt}\left(\mathrm{X}_{\mathrm{Mg}}=0.44\right)$, Crd $\left(\mathrm{X}_{\mathrm{Mg}}=0.83\right) ; \mathbf{D}=\mathrm{Bt}\left(\mathrm{X}_{\mathrm{Mg}}=0.80\right), \mathrm{Gt}\left(\mathrm{X}_{\mathrm{Mg}}=0.50\right), \quad$ Crd $\left(\mathrm{X}_{\mathrm{Mg}}=0.83\right) ; \mathbf{E}=\mathrm{Bt}$ $\left(X_{M g}=0.89\right)$, Gt $\left(X_{M g}=0.62\right), C r d\left(X_{M g}=0.92\right) ; 1=B t\left(X_{M g}=0.56\right)$, Gt $\left(X_{M g}=0.26\right)$, Opx $\left(\mathrm{X}_{\mathrm{Mg}}=0.42\right) ; 2=\mathrm{Bt}\left(\mathrm{X}_{\mathrm{Mg}}=0.64\right), \mathrm{Gt}\left(\mathrm{X}_{\mathrm{Mg}}=0.32\right), \mathrm{Opx} \quad\left(\mathrm{X}_{\mathrm{Mg}}=0.52\right) ; \mathbf{3}=\mathrm{Bt}$ $\left(\mathrm{X}_{\mathrm{Mg}}=0.72\right), \mathrm{Gt}\left(\mathrm{X}_{\mathrm{Mg}}=0.38\right), \mathrm{Opx}\left(\mathrm{X}_{\mathrm{Mg}}=0.62\right) ; \mathbf{4}=\mathrm{Bt}\left(\mathrm{X}_{\mathrm{Mg}}=0.72\right), \mathrm{Gt}\left(\mathrm{X}_{\mathrm{Mg}}=0.44\right)$, Opx $\left(X_{M g}=0.62\right) ; 5=B t\left(X_{M g}=0.80\right), G t\left(X_{M g}=0.50\right)$, Opx $\left(X_{M g}=0.71\right)$ 
ilmenite-rutile. Quartz and a fluid phase with $\mathrm{X}_{\mathrm{H}_{2} \mathrm{O}}=0.4$ have been assumed to be in excess. For garnet (Berman, 1990), cordierite (ideal), orthopyroxene (ideal), and biotite (ideal), solid solutions have been considered. Figure 7 shows a $P T$ grid which considers the relevant univariant and divariant reactions in the TKFMASH system. The reactions

$$
\begin{gathered}
\text { Biotite }+ \text { Sillimanite }+ \text { Quartz }=\text { Cordierite }+ \text { Garnet }+ \text { Sanidine }+\mathrm{H}_{2} \mathrm{O} \\
\text { Biotite }+ \text { Garnet }+ \text { Quartz }=\text { Cordierite }+ \text { Orthopyroxene }+ \text { Sanidine }+\mathrm{H}_{2} \mathrm{O} \\
\text { Garnet }+ \text { Rutile }+ \text { Quartz }=\text { Cordierite }+ \text { Orthopyroxene }+ \text { Ilmenite }
\end{gathered}
$$

enclose an area where the M2-G peak mineral assemblage must have equilibraed. Reaction 6 is commonly observed (Fig. 3c) and must have been overstepped. Reaction 7 marks the upper stability limit for the assamblage biotite-garnet-quartz, which can be observed in all thin sections, and therefore was not overstepped. Reaction 8 gives a minimum pressure estimate for the M2-G mineral assemblage in the TKFMASH system, because the mineral assemblage cordierite and orthopyroxene does not occur.

Garnets from M2-G mineral assemblages have usually a $\mathrm{X}_{\mathrm{Mg}}$ of 0.34 , Cordierite 0.80 , biotite 0.65 and orthopyroxene 0.65 . The small box within the gray shaded area in Fig. 7 indicates the $P T$ range of the granulite facies mineral assemblage (M2-G).

\section{Discussion}

Understanding the metamorphic history in the Sierras de San Luis requires knowledge of the tectonic evolution and its relationship to metamorphism. In this discussion we will start with an inferred $P T$ path based on the thermobarometric data discussed above. This $P T$ path will then be interpreted in terms of the possible heat sources for the metamorphism, which ultimately permits definition of the tectonic environment.

\section{Interpretation of a PT path}

A PT path for the CB has been constrained by applying several geothermobarometers, petrogenetic grids and mineral zonation pattern to M1-A, M2-G, and M3-A mineral assemblages (Fig. 8). Geographic and geometric field-relationships and geothermobarometric results are evidence for a prograde medium to high grade amphibolite facies metamorphism (M1-A) of this crustal section. Some samples preserve garnets with chemical zonation pattern consistent with prograde growth (Fig. 4a). The clear relationship of granulite facies metamorphism (M2-G) close to the numerous mafic intrusive bodies favour our model of a mafic intrusion being responsible for the granulite facies metamorphism. The calculated $P T$ conditions for M2-G by classical geothermobarometry and phase petrology differ significantly in pressure. The geobarometers are about $1 \mathrm{kbar}$ higher than estimates from the calculated phase diagram. Similarly, the $\mathrm{P}$ conditions for the M1-A mineral assemblage seem to be high. The larger part of the calculated $P T$ box lies within the kyanite stability field. In thin-sections only sillimanite could be identified as 


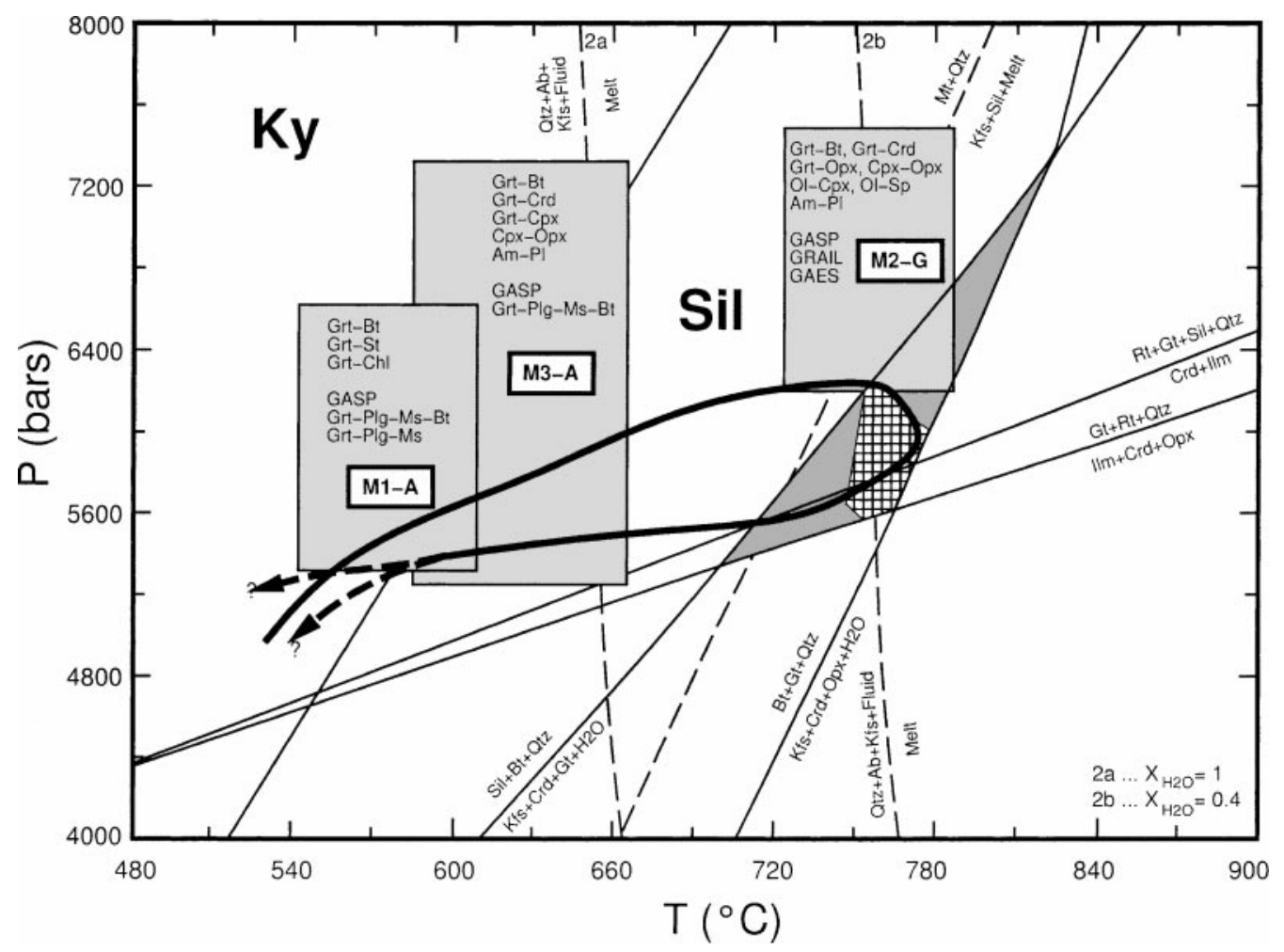

Fig. 8. PT - path for the central block (CB) of the Sierras de San Luis. The first amphibolite facies metamorphism took place at $570^{\circ} \mathrm{C}$ to $600^{\circ} \mathrm{C}$ and about $5.6 \mathrm{kbar}$. A mafic intrusion caused locally granulite facies metamorphism at a temperature of $740^{\circ} \mathrm{C}$ to $790{ }^{\circ} \mathrm{C}$ and 5.7 to $6.4 \mathrm{kbar}$. During cooling a mylonite zone retrograded most of the granulite facies rocks to amphibolite facies conditions at $590^{\circ} \mathrm{C}$ to 650 and about $5.5 \mathrm{kbar}$. Applied geobarometers tend to give too high pressure estimates compared to results from the petrogenetic grid

stable aluminium-silicate phase. The most likely cause for these discrepancies is the known fact that geothermo- and geobarometer may record 2 different points along a $P T$ path. We propose therefore a model, where the amphibolite facies basement M1-A with $P T$ conditions of $570^{\circ} \mathrm{C}$ to $600^{\circ} \mathrm{C}$ and 5 to $5.7 \mathrm{kbar}$ was intruded by a $\mathrm{N}-\mathrm{S}$ elongated mafic intrusion. Close to the contact of this intrusions, granulite facies mineral assemblages (M2-G) equilibrated around $740{ }^{\circ} \mathrm{C}$ to $790^{\circ} \mathrm{C}$ and 5.7 to $6.4 \mathrm{kbar}$ (Fig. 8). The pressure remained unchanged or increased slightly. The high temperatures during granulite facies metamorphism erased all prograde chemical zonation and garnets are characterized by homogeneous flat pattern and very low $\mathrm{Ca}$ and $\mathrm{Mn}$ contents. However, in one sample a Ca decrease from core to rim (Fig. 4d) could be found and indicates a growth during constant pressure and increasing temperature. The development of a mylonite zone close to the mafic intrusions gives us a good possibility to quantify the retrograde $P T$ path. The mylonite zone overprinted most of the M2-G mineral assemblages to amphibolite facies conditions M3-A. Due to disequilibrium effects during the overprint, the calculated $P T$ conditions significantly vary in this mineral paragenesis. A $\mathrm{T}$ of 
$555^{\circ} \mathrm{C}$ to $695^{\circ} \mathrm{C}$ and a $\mathrm{P}$ of 5.1 to $8.2 \mathrm{kbar}$ could be calculated. Fortunately, the Tiphases ilmenite and rutile give us a good constrain on the retrograde PT path. M2$\mathrm{G}$ mineral assemblages contain both Ti-phases, whereas M3-A mineral paragenesis contain only rutile. Ilmenite can still be found as inclusions in garnet (Fig. 3h). The calculated phase diagram (Fig. 7) shows that reaction

$$
\text { garnet }+ \text { rutile }+ \text { quartz }=\text { ilmenite }+ \text { cordierite }+2 \text { orthopyroxene }
$$

gives the lower P limit of the retrograde $P T$ path. In order to produce rutile the basement rocks must have passed through the small $P T$ range between reaction 9 and reaction

$$
\text { garnet }+ \text { rutile }+ \text { quartz }+ \text { sillimanite }=\text { ilmenite }+ \text { cordierite }
$$

(Fig. 8). During the overprint of the M2-G mineral assemblage by mylonitization, garnets have developed either retrograde diffusion pattern (Fig. 4g), formed new small grains of garnet (Fig. 3h), or formed newly grown rims (Fig. 3f,g).

The age of the three different metamorphic events M1-A, M2-G, and M3-A of the Sierras de San Luis has not been well established. Magmatic rocks which are intercalated in this basement, have yielded ages between 403 to $490 \mathrm{ma}$. (Sims et al., 1998; Llambias et al., 1998). We assume therefore that the M1-A metamorphism of the basement belongs to the early stage of the Famatinian orogeny at around 490 to $500 \mathrm{ma}$. The granulite facies metamorphism M2-G took place during the intrusion of the mafic rocks which was determined by Sims et al. (1998) at $478 \pm 6$ ma. The mylonitization most likely occurred shortly after the mafic intrusion and may coincide with the intrusions of granites and tonalites.

\section{Interpretation of a heat source}

The $P T$ path derived in the last section is characterized by near isobaric cooling following the metamorphic temperature peak. This implies that the rate of cooling was much more rapid than the rate of depth change. Thus, such paths have been interpeted as an indication for advective heating events, which are typically extremely short-lived processes (Lux et al., 1986; Bohlen, 1987; Stüwe et al., 1993). In contrast, Harley (1989) and others have argued that the absence of pervasive intrusive activity in many granulite terrains indicates that other heating mechanisms must be invoked. Unusual thickness geometries of crust and mantle lithosphere are assumed to account for the unusual metamorphic conditions and the retrograde $P T$ path. In the Sierras de San Luis, the spatial association between granulites and mafic intrusions suggests that there is a genetic link. The concept of granulite facies metamorphism in the centre of the belt being caused by mafic intrusions can be tested by a simple heat budget estimate based on a volumetric comparison of granulite facies rocks and heat source. By assuming that the intrusion temperature was about $1200^{\circ} \mathrm{C}$ and the surrounding basement rocks at the time of intrusion about $550{ }^{\circ} \mathrm{C}$, an area about 5 times the outcrop area of the mafic intrusions can be heated from $550^{\circ} \mathrm{C}$ to $750{ }^{\circ} \mathrm{C}$. The volume of mafic lenses, which has been estimated using geophysical methods by Kostadinoff et al. (1998), are large enough to produce the observed granulite facies rocks, if the T estimates are valid. 
Granulite facies terranes are usually characterized by low water activities, which could result either from a $\mathrm{CO}_{2}$ dominated fluid or under fluid absent conditions (Lamb and Valley, 1988; Hansen et al., 1984; Edwards and Essene, 1988; Bhattacharya and Seb, 1986). The widespread occurrence of migmatites suggest that water activity in the fluid phase was high $\left(\mathrm{X}_{\mathrm{H}_{2} \mathrm{O}}>0.4\right)$ at the beginning of granulite facies metamorphism (emplacement of the mafic intrusion), was reduced at the peak of metamorphism to values corresponding to a $\mathrm{X}_{\mathrm{H}_{2} \mathrm{O}}$ of $0.2-0.5$.

\section{Conclusions}

The central block of the Sierras de San Luis is a good example of locally occuring granulite facies metamorphism caused by mafic intrusions. The geothermobarometric results have shown that $P T$ estimates from geothermometers/geobarometers and phase diagrams differ significantly and may not record the same points along the $P T$ path.

The $P T$ conditions of M1-A are about $570{ }^{\circ} \mathrm{C}$ to $600{ }^{\circ} \mathrm{C}$ and 5 to $5.7 \mathrm{kbar}$, of $\mathrm{M} 2-\mathrm{G} 740{ }^{\circ} \mathrm{C}$ to $790^{\circ} \mathrm{C}$ and 5.7 to $6.4 \mathrm{kbar}$, and for M3-A $590^{\circ} \mathrm{C}$ to $650{ }^{\circ} \mathrm{C}$ and 5.4 to $6 \mathrm{kbar}$. The observed mineral reactions in combination with a calculated phase diagram allowed to draw an accurate nearly isobaric heating and cooling PT path of the metamorphic evolution of this part of the Sierras de San Luis (Fig. 8).

Harley (1989) gives an overview of $P T$ paths derived from various amphibolite and granulite grade terranes. Some areas (see references in Harley, 1989) exhibit essentially isothermal decompression paths (ITD) during the initial stages of retrogression, whereas in others (see references in Harley, 1989) nearly isobaric cooling (IBC) has occurred. This has led to several tectonic models for the formation of high grade crustal rocks: 1) ITD-paths: Following a rapid increase in pressure, the path follows a nearly isobaric heating till peak of metamorphism is reached, then the retrograde path begins with a nearly isothermal uplift related to erosion or tectonic exhumation and later a monotonous decrease in pressure and temperature (England and Thompson, 1984). 2) IBC-paths: Nearly isobaric cooling paths imply that (a) metamorphism was caused by an intrusion of a magma that underplated and heated the whole terrane (Sandiford and Powell, 1986; Bohlen, 1987), (b) granulites were formed by extension of normal thickness crust without additional magmatic inputs as major external heat source (Sandiford and Powell, 1986), and (c) metamorphism was caused by erosion or extension of formerly overthickened crust in a collisional setting (England and Thompson, 1984).

The deduced IBC path of the basement of the central block (CB) of the Sierras de San Luis and the genetic relationship of gabbroic intrusions with basement rocks favour a tectonic setting as proposed by Bohlen (1987). The most likely geological setting for areas with high heat input at relatively low pressures is a back-arc region. A very similar geological setting is reported by Grissom et al. (1998) further north in the Sierras de Fiambala. A mafic intrusion caused granulite facies metamorphism at $\mathrm{T}=690^{\circ} \mathrm{C}$ to $870^{\circ} \mathrm{C}$ and relatively low pressures of 5 to $8.5 \mathrm{kbar}$. Although the age of both intrusions seem to differ by about $30 \mathrm{my}$, the similar geological setting of both areas suggest that during the Pampean/Famatinian orogeny a back-arc basin with extensive intrusive activities has developed. 


\section{Acknowledgements}

Financial support by the Austrian Research Fund FWF (P10623-TEC) to A.M. and G.H. and the Argentinian CONICET to J.K. and E.B. is gratefully acknowledged. The authors thank D. Moecher and F. Lucassen, who revised an earlier version of this manuscript, and the reviewers $S$. Harley and $K$. Stüwe for their critical and helpful comments, which improved the manuscript considerably. In addition, $K$. Stüwe is thanked for many interesting discussions.

\section{References}

Ballhaus C, Berry RF, Green DH (1991) High pressure experimental calibration of the olivine-orthopyroxene-spinel oxygen geobarometer: implications for the oxidation state of the upper mantle. Contrib Mineral Petrol 107: 27-40 (+Erratum)

Berman $R G$ (1990) Mixing properties of Ca-Mg-Fe-Mn garnets. Am Mineral 75: 328-344

Berman RG, Aranovich LY, Pattison DRM (1995) Reassessment of the garnet-clinopyroxene $\mathrm{Fe}-\mathrm{Mg}$ exchange thermometer. 2. Thermodynamic analysis. Contrib Mineral Petrol 119: $30-42$

Bhattacharya A, Sen SK (1986) Granulite metamorphism, fluid buffering, and dehydration melting in the Madras charnockites and metapelites. J Petrol 27: 1119-1141

Bhattacharya A, Mazumdar AC, Sen SK (1988) Fe-Mg Mixing in cordierite - constraints from natural data and implications for cordierite-garnet geothermometry in granulites. Am Mineral 73: 338-344

Bjerg EA, Delpino S, Dimieri L, Kostadinoff J, Mogessie A, Hoinkes G, Hauzenberger CA, Felfernig A (1997) Estructura y Mineralizacion del Area Las Aguilas - Virorco, San Luis, Argentina. VIII Congreso Geologico Chileno, Actas, Antofagasta, Chile, II, pp 857-861

Bohlen SR (1987) Pressure-temperature-time paths and a tectonic model for the evolution of granulites. J Geol 95: 617-632

Bohlen SR, Wall VJ, Boettcher AL (1983) Experimental investigation and application of garnet granulite equilibria. Contrib Mineral Petrol 83: 52-61

Bonorino FG (1961) Petrologia de Algunos Cuerpos Basicos de San Luis. Revista de la Asocicion Geologica Argentina 16: 61-106

Brey GP, Köhler T (1990) Geothermobarometry in four-phase lherzolites. II. New thermobarometers, and practical assessment of existing thermobarometers. J Petrol 31: 1353-1378

Coira BL, Davidson JD, Mpodozis C, Ramos VA (1982) Tectonic and magmatic evolution of the Andes of Northern Argentina and Chile. Earth Sci Rev 18: 303-332

Connolly JAD (1990) Multivariable phase-diagrams - an algorithm based on generalized thermodynamics. Am J Sci 290: 666-718

Connolly JAD, Kerrick DM (1987) An algorithm and computer program for calculating composition phase diagrams. CALPHAD 11: 1-55

Dachs E (1998) PET: petrological elementary tools for mathematica. Comp Geosci 24: 219-235

Dalla Salda L (1987) Basement tectonics of the Southern Pampean Ranges, Argentina. Tectonics 6: 249-260

Edwards RL, Essene EJ (1988) Pressure, temperature and C-O-H fluid fugacities across the amphibolite-granulite transition, Northwest Adirondack Mountains, New York. J Petrol 29: 39-72

England PC, Thompson AB (1984) Pressure-temperature-time paths of regional metamorphism. I. Heat transfer during evolution of regions of thickened continental crust. J Petrol 25: 894-928 
Frost BR, Frost CD (1987) $\mathrm{CO}_{2}$, melts and granulite metamorphism. Nature 327: 503-506 Fuhrman ML, Lindsley DH (1988) Ternary-feldspar modeling and thermometry. Am Mineral 73: 201-215

Fyfe WS (1973) The granulite facies, partial melting and the Archean Crust. Phil Trans Roy Soc Lond A 273: 457-461

Gerth $H$ (1913) Die pampinen Sierren Centralargentiniens. Geol Rundschau (Stuttgart) 4: $577-588$

Gervilla F, Sanchez-Anguita A, Acevedo RD, Hach-Ali PF, Paniagua A (1997) Platinumgroup element sulpharsenides and Pd bismuthotellurides in the metamorphosed $\mathrm{Ni}-\mathrm{Cu}$ deposit at Las Aguilas (Province of San Luis, Argentina). Min Mag 61: 861-877

Gordillo CE, Lencinas AN (1979) Sierras Pampeanas de Cordoba y San Luis. Apartado de Geologia Regional Argentina 1: 577-650

Grissom GC, DeBari SM, Snee LW (1998) Geology of the Sierra de Fiambala, northwest Argentina: implications for Early Oalaeozoic Andean tectonics. In: Pankhurst RJ, Rapela CW (eds) The proto-Andean Margin of Gondwana. Geol Soc London, Spec Publ 142: 297-323

Hoisch TD (1991) Equilibria within the mineral assemblage quartz+muscovite+biotite+ garnet+plagioclase, and implications for the mixing properties of octahedrallycoordinated cations in muscovite and biotite. Contrib Mineral Petrol 108: 43-54

Hand M, Scrimgeour I, Stüwe K, Powell R, Wilson C (1994) Metapelitic granulites from Jetty Peninsula, East Antarctica: formation during a single event or by polymetamorphism? J Metam Geol 12: 557-573

Hansen EC, Newton RC, Janardhahn AS (1984) Fluid inclusions in rocks from the amphibolite-facies gneiss to charnockite progression in Southern Karnataka, India: direct evidence concerning the fluids of granulite metamorphism. J Metam Geol 2: 249-264

Harley $S$ (1989) The origins of granulites: a metamorphic perspective. Geol Mag 126: 215-247

Hauzenberger CA, Mogessie A, Hoinkes G, Felfernig A, Bjerg EA, Kostadinoff J (1996) Platinum group minerals from the Las Aguilas Ultramafic Unit, San Luis Province, Argentina. Mitt österr Mineral Ges 141: 157-159

Hauzenberger CA, Mogessie A, Hoinkes G, Bjerg EA, Kostadinoff J, Delpino S, Dimieri L (1997) Platinum group minerals in the basic to ultrabasic complex of the Sierras de San Luis, Argentina. In: Papunen $H$ (ed) Mineral deposits: research and explorations where do they meet? Balkema, Rotterdam, pp 439-442

Holland T, Blundy J (1994) Nonideal interactions in calcic-amphiboles and their bearing on amphibole-plagioclase thermometry. Contrib Mineral Petrol 116: 433-447

Hollister LS (1990) Enrichment of $\mathrm{CO}_{2}$ in fluid inclusions. J Struct Geol 12: 895-901

Johannes W, Holtz F (1996) Petrogenesis and experimental petrology of granitic rocks. Springer, Berlin Heidelberg New York Tokyo, p 36

Jordan TE, Allmendinger RW (1986) The Sierras Pampeanas of Argentina: a modern analogue of Rocky Mountain Foreland deformation. Am J Sci 286: 737-764

Jordan TE, Isacks BL, Ramos VA, Allmendinger RW (1983) Mountain building in the Central Andes. Episodes 3: 20-26

Kleemann U, Reinhardt $J$ (1994) Garnet-biotite thermometry revisited - the effect of $\mathrm{Al}(\mathrm{VI})$ and $\mathrm{Ti}$ in biotite. Eur J Mineral 6: 925-941

Koziol AM (1989) Recalibration of the garnet-plagioclase- $\mathrm{Al}_{2} \mathrm{SiO}_{5}$-quartz (GASP) geobarometer and application to natural paragenesis. EOS Trans Am Geophys Union 70: 493

Kostadinoff J, Bjerg E, Delpino S, Dimieri L, Mogessie A, Hoinkes G, Hauzenberger C, Felfernig A (1998) Gravimetric and magnetometric anomalies in the Sierras Pampeanas of San Luis, Argentina. Asoc Geol Argentina 53: 169-179 
Lamb W, Valley $J W(1988)$ Granulite facies amphibole and biotite equilibria, and calculated peak-metamorphic water activities. Contrib Mineral Petrol 100: 349-360

Lal RK (1993) Internally consistent recalibrations of mineral equilibria for geothermobarometry involving garnet ortho-pyroxene plagioclase quartz assemblages and their application to the South Indian granulites. J Metam Geol 11: 855-866

Llambias EJ, Sato AM, Ortiz Suarez A, Prozzi C (1998) The granitoids of the Sierras de San Luis. In: Pankhurst RJ, Rapela $C W$ (eds) The proto-Andean margin of Gondwana. Geol Soc London, Spec Publ 142: 325-341

Lux D, Decker E, Deyoreo J, Guldotti C (1986) Role of plutonism in low-pressure metamorphic belt formation. Nature 323: 794-797

Malvicini L, Brogioni N (1992) El yacimiento hidrotermal de niquel, cobre y metales del "Grupo del Platino", Las Aguilas Este, Prov. de San Luis, Argentina. Americano de Geologia Economica, Acta Cordoba: 93-102

Mierwald P (1986) Ist Cordierit ein Geothermometer? Fortsch Mineral 64 Bh1: 119

Mogessie A, Hoinkes G, Stumpfl EF, Bjerg EA, Kostadinoff J (1994) The petrology and mineralization of the basement and associated mafic - ultramafic rocks, San Luis Province, Central Argentina. Mitt österr Mineral Ges 139: 347-348

Mogessie A, Hoinkes G, Stumpf EF, Bjerg EA, Kostadinoff J (1995) Occurrence of Platinum Group Minerals in the Las Aguilas ultramafic unit within a granulite facies basement, San Luis Province, Central Argentina. In: Pasava J, Kribek B, Zak K (eds) Mineral deposits: from their origin to their environmental impacts. Balkema, Rotterdam, pp 897-900

Mogessie A, Hauzenberger CA, Hoinkes G, Felfernig A, Stumpfl EF, Bjerg EA, Kostadinoff $J$ (1996) Platinum Group Minerals from the Las Aguilas ultramafic unit, San Luis Province, Argentina. Mitt österr Mineral Ges 141: 157-159

Newton RC, Smith JV, Windley BF (1980) Carbonic metamorphism, granulites and crustal growth. Nature 288: 45-50

Pankhurst RJ, Rapela CW (1998) The proto-Andean margin of Gondwana: an introduction. In: Pankhurst RJ, Rapela CW (eds) The proto-Andean margin of Gondwana. Geol Soc London, Spec Publ 142: 1-9

Pankhurst RJ, Rapela CW, Saavedra J, Baldo E, Dohlquist J, Pascua I, Fanning CM (1998) The Famatinian magmatic arc in the central Sierras Pampeanas: an Early to MidOrdovician continental arc on the Gondwana margin. In: Pankhurst RJ, Rapela CW (eds) The proto-Andean margin of Gondwana. Geol Soc London, Spec Publ 142: 343-367

Perchuk LL (1991) Derivation of a thermodynamically consistent set of geothermometers and geobarometers for metamorphic and magmatic rocks. In: Perchuk LL (ed) Progress in metamorphic and magmatic petrology. Cambridge University Press, Cambridge, pp 93-111

Powell M, Powell R (1974) An olivine-clinopyroxene geothermometer. Contrib Mineral Petrol 48: 249-263

Ramos VA (1988) Late proterozoic-early paleozoic history of South America - a collisional history. Episodes 11: 168-174

Ramos VA, Jordan TE, Allmendinger RW, Mpodozis C, Kay S, Cortes JM, Palma MA (1986) Paleozoic terranes in the Central Argentine - Chilean Andes. Tectonics 5: 855880

Rapela CW, Shaw DM (1979) Trace and major element models of granitoid genesis in the Pampean Ranges, Argentina. Geochim Cosmochim Acta 43: 1117-1129

Rapela CW, Heaman LM, McNutt RH (1982) Rb/Sr Geochronology of granitoid rocks from the Pampean Ranges, Argentina. J Geol 90: 574-582

Rapela CW, Saavedra J, Encarnacion Pelitero AT (1986) Geology, structure, and metamorphism in the area south of La Carolina (Sierra de San Luis, Argentina). XIII 
126 C. A. Hauzenberger et al.: Metamorphic evolution of the Sierras de San Luis

Congreso Geológico Argentino y III Congreso de Exploracion Hidrocarburos, Actas II: 337-353

Rapela CW, Pankhurst RJ, Baldo E, Saavedra J (1995) Cordierites in S-type granites: restites following low pressure, high degree partial melting of metapelites. Third Hutton Symposium, U.S. Geological Survey Circular 1129: 120-121

Rapela CW, Pankhurst RJ, Casquet C, Baldo E, Saavedra J, Galindo C (1998) Early evolution of the Proto-Andean margin of South America. Geology 26: 707-710

Sabalua JC (1986) Yacimiento Las Aguilas. Mineralizacion Ni-Cu-Co. Departamento Pringles, Provincia San Luis, Republica Argentina. Informe Final, DGFM, Subdireccion de Desarrollo Minero, Centro de Exploracion Geologico Minero, Mendoza

Sandiford M, Powell $R$ (1986) Deep crustal metamorphism during continental extension: modern and ancient examples. Earth Planet Sci Lett 79: 151-158

Sengupta P, Dasgupta S, Bhattacharya PK, Mukherjee M (1990) An orthopyroxene-biotite geothermometer and its application in crustal granulites and mantle-derived rocks. $\mathbf{J}$ Metam Geol 8: 191-197

Sims JP, Ireland TR, Camacho A, Lyons P, Pieters PE, Skirrow RG, Stuart-Smith PG, Miro $R$ (1998) U-Pb, Th- $\mathrm{PB}$ and Ar-Ar geochronology from the southern Sierras Pampeanas, Argentina: implications for the Paleozoic tectonic evolution of the western Gondwana margin. In: Pankhurst RJ, Rapela CW (eds) The proto-Andean margin of Gondwana. Geol Soc Lond, Spec Publ 142: 259-281

Spear F, Cheney $J$ (1989) A petrogenetic grid for the pelitic schists in the system $\mathrm{SiO}_{2}-$ $\mathrm{Al}_{2} \mathrm{O}_{3}-\mathrm{FeO}-\mathrm{MgO}-\mathrm{K}_{2} \mathrm{O}-\mathrm{H}_{2} \mathrm{O}$. Contrib Mineral Petrol 101: 149-164

Stüwe K, Powell R (1989) Low pressure granulite facies metamorphism in the Lasermann Hills Area, East Antarctica: petrology and tectonic implications for the evolution of the Prydz Bay Area. J Metam Geol 7: 465-483

Stüwe K, Sandiford M, Powell $R$ (1993) On the origin of repeated metamorphicdeformation events in low-P high-T terranes. Geology 21: 829-832

Valley JW (1985) Polymetamorphism in the Adirondacks: wollastonite at contacts of shallowly intruded anorthosite. In: Tobi AC, Tour JLR (eds) The Deep Proterozoic Crust in the North Atlantic Provinces. Reidel, Dordrecht, pp 217-236

Von Gosen W (1998) The phyllite and micaschist group with associated intrusions in the Sierras de San Luis (Sierras Pampeanas/Argentina) - structural and metamorphic relations. J South Am Earth Sci 11: 79-109

Authors' addresses: C. A. Hauzenberger, A. Mogessie, G. Hoinkes, A. Felfernig, Institute of Mineralogy and Petrology, Karl-Franzens University Graz, A-8010 Graz, Austria; E. A. Bjerg, J. Kostadinoff, S. Delpino, L. Dimieri, Department of Geology, Universidad Nacional del Sur, Bahia Blanca, Argentina 